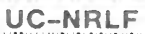 \\ || ||||||||||||||||||||||
}

支B

$\ulcorner 4$

H.t.

Pate 然

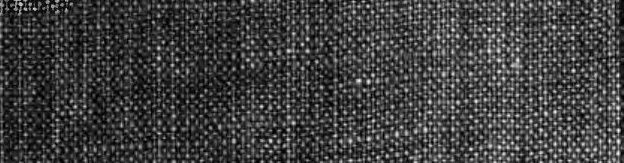
(1)

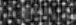



Digitized by the Internet Archive in 2007 with funding from

Microsoft Corporation 


\section{THE GROWTH OF THE GOSPELS}




\title{
THE GROWTH OF THE GOSPELS
}

AS SHEWN BY STRUCTURAL CRITICISM

\author{
BY W. M. FLINDERS PETRIE \\ D.C.L., LL.D., F.R.S., F.B.A.
}

THE BAKER AND TAYLOR COMPANY NEW YORK

1910 


$$
B 52545
$$




\section{O N T E N T S}

\section{CHAPTER I}

The Archaeological View

1. The Gospels and the Logia

2. The Habit of Writing .

3. Early Need of Gospels .

4. An Impersonal Criticism Required $\quad$. 8

\section{CHAPTER II \\ Structural Criticism}

5. The Examination of Structure . • . 11

6. The Classes of Episodes _ . $\quad$. 13

7. The Apparatus for Study $\quad$. $\quad$. 18

\section{CHAPTER III}

The Classes of Documents

8. The Nucleus (i).

9. The Two-gospel Sequences (ii). . . 22

10. The Scattered Documents (iii) . 24

11. The Use of Doublets . . . . 27

12. The Disintegrated Documents (iv) . $\quad$. 29

13. The Isolated Episodes (v) . $\quad$. $\quad$. 31

14. The Unrepeated Episodes (vi). . . $\quad 31$ 


\section{CHAPTER IV}

\section{Historical Connections}

15. The Decades of Church History . . $\quad 33$

16. The Historic Position of the Nucleus . . 38

17. The Two-gospel Additions $\quad$. $\quad$. $\quad$. 42

18. Connections of Scattered Documents . $\quad$. 46

19. Changes in Expressions $\quad$. $\quad$. $\quad$. 47

20. The Latest Additions . $\quad$. $\quad$. $\quad$. 49

21. Summary $\quad$. $\quad$. $\quad$. $\quad$. $\quad$. 52

\section{APPENDIX}

The Nucleus and other Separate Documents $\quad$ - $\quad 57$

The Choice between Matthew and Mark . $\quad$. 86

Table I. Documents composing Matthew's Gospel . 90

Table II. Documents composing Mark's Gospel 92

Table III. Documents composing Luke's Gospel . 94

Table IV. Documents in Sequence in Two Gospels

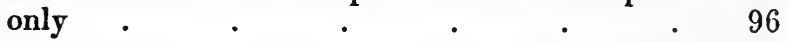

Table V. Documents in Sequence independently used . $\quad . \quad$. $\quad . \quad$. $\quad .97$

Table VI. Scattered Documents • • $\quad$ • 98

Table VII. Doublet Verses . $\quad$. $\quad$. $\quad$. 99 


\section{THE GROWTH OF THE GOSPELS}

\section{CHAPTER I}

THE ARCHAEOLOGICAL VIEW

\section{The Gospels and the Logia.}

THE fundamental question of the relation of the Gospels to each other must precede any exact understanding of their teaching. Until some means of discrimination are gained, it is impossible to decide which of the slightly varying accounts should be accepted as the more correct, or which sayings or episodes may be the more precisely recorded.

It is evident that the means of judging of these matters lie before us, in a triple account, which varies in its detail and its order. But what conclusions are to be drawn from these variations is greatly debated. The only out- 
line generally agreed upon is that the gospel according to St Matthew and that according to St Luke are both derived from the sources of the gospel according to St Mark, with the addition of much more material. And our present conclusions here, from a more impersonal research, agree in this.

The dominant point of view hitherto has been mainly literary and subjective, and hence it has been largely influenced by personal judgment. The position in the present day to such questions is rather based on the comparative view of the conditions and life of the age in question. The previous views have been implicitly influenced by the older conception of a writer sitting down to write a whole gospel as an entire work of his own. The gradual accretion of historical records side by side, like the monastic chronicles, is now felt to be more in accord with a wide-spread need of documents in the early churches. The assumption that the pre-existing material was only oral, and was first put in writing by an evangelist, has been widely removed by the appearance of the logia as a living actuality.

Although from the time of the earliest 
discussions on the gospels the existence of collections of sayings, or logia, had been recognised, yet they remained rather as a literary abstraction. The finding, in recent years, of the fragments of actual collections of $\operatorname{logia}^{1}$ has changed our mental atmosphere and realisation of the subject, though it has not added to the material for solving the questions. It is one thing to read of the existence of logia, or sayings, in some ancient writer or in modern discussions, but it gives quite a different sense of the actualities of history to see the papyrus leaf of sayings. And when we realise that this is only one leaf out of a volume of sayings, and that there may have been only one or two copyings between that and the notes which were made by the disciples themselves, we seem to have come into living contact with the original facts.

The sight of such material, in a far less literary setting than we see it in the gospels, at once raises a new field of questions. Between the logia and a gospel there is a difference like that between a note-book and a treatise.

${ }^{1}$ New Sayings of Jesus, by B. P. Grenfell and A. S. Hunt, 1904. 
The logia are like a loose handful of gems from which a rich piece of jewellery may be constructed, with its gradations and contrasts. The setting of surrounding narrative, the linking of ideas, and the balancing of effects are the work of the evangelists incorporating the materials. We pause at many enquiries. How early were such logia written down? Were they circulated before the gospels? How widely were they known? How far were they incorporated in the gospels? How were they used for extracts? Were whole documents taken as they stood, or were they all broken up and reset by the writers? The growth of the gospels is brought vividly before the historic imagination when we see a portion of the working material in our hands for the first time.

\section{The Habit of Writing.}

There has been a very general impression that writing was in all ancient times a special accomplishment,-an idea which is based on the general illiteracy of Europe down to a century ago. But we now realise that in the Roman age, and in earlier times in the East, 
writing was familiar to the lower classes. Even from early Babylonia we see that ordinary tradespeople - men and women kept their own accounts and correspondence. The papyri of Roman age found in recent years in Egypt are commonly of the most trivial character, like present notes and bills. The roughest scrawled list of daily marketing by a cook, full of mis-spellings, shews that writing was a matter of common knowledge, and not of precise education. The blundering, crabbed hand of a petition of some peasants shews that they could read and write without needing to go to a professional scribe. Their very faults are evidence that the use of the pen was not at all limited to what we should call an educated class.

We should remember how early in the gospel narrative we have recorded, by all three synoptics, the call of Matthew, or Levi, a taxgatherer. He must have spent his life down to that time in writing tax-receipts, those documents which have been preserved by the thousand on the potsherds of Egypt. He had lived with a pen in his hand most of the day; and can it then be supposed that when he left 
his business for what he saw to be a far higher interest, his habit of writing would be dropped? See what was going on in that century. Any teacher who had a following, was accompanied by a friend who recorded his sayings. Apollonios the wanderer had his Damis, and the slave Epictetus had his Arrian. It would be contrary to all we know if we were wilfully to imagine that when men gave their lives up to the new Way their great pre-occupation was not thought worth a memorandum.

Thus we see that the known historical conditions of the age, the generally recorded presence of at least one ready scribe, the fact of many collections of sayings having early come into circulation, all compel us to look on the period of the ministry of Jesus and of the early Church in Jerusalem as a time of notemaking and compiling.

\section{Early Need of Gospels.}

When we observe the date at which the various churches were springing up-at Antioch in 42 A.D., at Alexandria probably earlier, in Asia Minor before 50 A.D., and in 
Greece soon after-it is impossible to suppose that they were left at that time without a written account of the principal events and teaching which they were wishing to follow. Some generally accepted gospels must have been already in circulation before 60 A.D. The mass of briefer records and logia, which the habits and culture of that age would naturally produce, must have been welded together within ten or twenty years by the external necessities.

The historical conditions of continual accretion and incorporation of documents, during perhaps a generation, have been too generally ignored. Yet we cannot doubt that such was the course of growth when we look at the logia. Those collections of brief sayings could hardly have come into existence if full narratives, and sufficient standards of information in the gospels, were already circulating. They belong essentially to a preparatory age, when records were in course of compilation. But, once written out, they naturally survived side by side with the gospels, which had only used a portion of their material.

Some familiarity with the history of other 
ancient literature is needed before we can realise the conditions of the question before us. It is the wide documentary training which gives such force and common-sense to the work of that great scholar, Blass, in his Philology of the Gospels.

\section{An Impersonal Criticism Required.}

The whole course of verbal criticism, and even of textual criticism, is rendered more difficult in the gospels than it is in any other work, by the incessant assimilations which have been made in parallel passages. Every ancient scribe thought he had a pious liberty, if not a call of duty, to eliminate differences between the gospels. Not only were verbal rectifications made to unify texts, but whole parallels and explanations which one generation had put in the margin, were by a later generation incorporated in the text. As Jerome says of the Latin text, there were almost as many versions as there were copies. And the work of any recensor, such as Jerome, would inevitably be to reject the divergent readings in favour of the unifying of the texts. Hence, even apart from all doctrinal changes 
(of - which many are known), the mere conditions alone would lead to frequent alterations from the original documents. All verbal criticism is thus vitiated at the source.

Further, a criticism which depends on personal judgment will inevitably reflect personal variation. If we try to judge which is the fresher or more natural narrative, the whole play of personal taste influences the decision. If we try to estimate whether one narrative has been expanded or another has been condensed, the whole personal equation of style sways the balance. Could it be expected that two students whose favourite authors respectively were Tacitus and Lucian could judge style alike? All such judgments must depend so greatly on taste and predilections, that it is hopeless to base on them an opinion which shall command general assent. We need, then, a form of criticism which shall be free of the personal judgment, which shall depend on the purely impersonal application of some general principles.

Before going further, we may for clearness' sake define the terms as here used. A group or block, is a piece of a document, or a whole 
document, which consists of several separable paragraphs or episodes. An episode is a portion containing a narrative or a saying which can stand by itself as a whole. These are the subjects of Structural Criticism. An incident is a dependant part of an episode, and a phrase records part of an incident. These are studied in Textual Criticism. The separate words are dealt with by Verbal Criticism. Any statement which can be brought into contact with facts otherwise known, becomes a subject for Historical Criticism. 


\section{CHAPTER II}

\section{STRUCTURAL CRITICISM}

5. The Examination of Structure.

THE study of the structure of a composite document, where it can be compared with others, promises to lead us to a form of criticism which is free from the inherent defects which we have noticed in verbal and textual criticism. When once we adopt the elementary conceptions of the superposition of documents, the study of structure can go forward entirely impersonally ; indeed it is best to keep out of sight altogether the sense of the document as long as possible, and deal only with references to chapters and verses, to label the blocks or groups and handle them regardless of the meaning. The ground is thus prepared with complete impartiality for the exercise of judgment and for subsequent historical criticism. 
The inevitable tendency to unification in the details of the gospels can seldom influence the structure, but was generally spent on words and phrases. The order of passages does not attract attention like differences of detail; it does not suggest to busybodies the need of alteration, as do the verbal differences. Moreover, structure cannot be changed except when recopying a manuscript, and it must be a matter of much more determination and care than the scratching of a word or the insertion of some note which lay hitherto in the margin. The structure is embedded safely below the surface, scarcely noticed, difficult to change. The verbal detail is at the mercy of every reader. There is much the same difference which there is between the somatic structure of an animal and its external form liable to mutilation.

And the structure carries with it not only so decisive a voice, but also such an amount of detail, that it promises to lead us far in understanding the historical growth of the gospels.

Hitherto the separation into three-gospel narrative and two-gospel narrative has been the main recognition of structure. But we are 
led very much farther than that when we follow it systematically.

Once grant the conception of a composite document, framed by the accretion of earlier documents, selected and arranged by an editor, and it becomes obvious that we may expect to find some traces of the original divisions. If, further, we have three such composite documents, based on similar, and sometimes the very same, materials, it is obvious that their agreements and differences will indicate the various limits of the component parts. No other postulates than these are required. The processes of this structural criticism will be best understood by seeing its practical application to the actual problem of the synoptic gospels. The gospel of John is clearly supplementary to the others, and hence it cannot be treated with them in our methodic process. We here deal only with the three synoptic gospels.

\section{The Classes of Episodes.}

On comparing the synoptic gospels, we see that they are composed of many different classes of material. Quite irrespective of the 
sense, the mere position alone, as compared with the position of the similar passage in another gospel, may vary in many different ways. To study the position and structure, we should regard the separate episodes solely as units labelled by chapter and verse, equivalent to other units in other gospels. We must only regard their comparative positions; and we must not consider their meaning until their purely structural relations are explored.

In considering the structure, there is not only the presence of any episode to be noted, but the sequence of it with other episodes. It may stand in the same relative order toward surrounding episodes, or toward large masses of separated episodes, or toward a scattered chain of episodes. And these relations may occur in any two or all three gospels.

The first and most obvious course is to remove from each gospel every episode which does not occur in the same order in both of the other gospels. Everything that is not in common to all three in a parallel text, should be set aside. Thus there remains a body of episodes which is identical in order in all three gospels. This must be the Nucleus or common 
basis on which each gospel has been built. It may have been larger originally, if any gospel has omitted matter from the Nucleus. It cannot have been smaller, as it is very unlikely that additional episodes would have been inserted at the same places in the Nucleus by separate writers. The Nucleus very probably grew out of shorter documents; and in some cases we can judge that a passage breaks the thread of idea and has probably been inserted, or that a natural close can be detected. But such personal estimates cannot be taken into account at this stage. Here we are only observing that a definite stage of documentary accretion was reached where the Nucleus passed as a whole, in unvaried order, into different lines of growth leading to several gospels. The utmost variation in sequence that may be tolerated is the inversion of two verses or short episodes by a literary author like Luke; their juxtaposition is fair proof that their places were already fixed and that we have not to deal with a random insertion.

The second class of documents after the Nucleus are the episodes, which only occur in two gospels in the same relation to the Nucleus. 
Here we have apparently the work used in common by two writers, but unknown to the third, or used by him quite independently in another connection. In some cases such episodes may have been parts of the Nucleus, but have been deliberately omitted by a third writer. But considering that all the evangelists largely expanded the Nucleus, it is very unlikely that they should have omitted any part of it.

The third class of documents are those groups of episodes which occur in the same relation one to another, but are inserted at different parts of the preceding structure by the writers who use them. Their relative order together being the same, though in different gospels, proves that they belong to a single document, which was adopted and used by different writers independently.

The fourth class is a small one, of scattered episodes or short sayings, which may be detected in the same order in different gospels, although widely separated. They are apparently due to a document having been utilised by extracting sayings from it and inserting them one after another in appropriate places. 
All of the preceding classes are probably from documentary sources, as the exact sequence of the portions of them is their distinctive mark.

The fifth class is of isolated episodes or sayings which are never found in the same immediate connection or in the same scattered order in any two gospels. From their positions they are more probably derived from oral tradition, or from single detached notes and memoranda which did not preserve any connection of sequence between different episodes.

The sixth class is the residuum of the material which is only found in a single gospel, and on which comparative structure has nothing to say.

It will be seen that in such a classification of the material there is no room for personal opinion. The facts arrange themselves so soon as these successive stages of sorting are applied. We have an absolutely impersonal critical engine which will produce exactly the same result, whoever may be the operator.

Thus there is obtained a firm platform for subsequent historical discussion and for more personal judgment of detail. 


\section{The Apparatus for Study.}

As it may not be clear what means of study are required in order to form an opinion on the subject, the following apparatus may be specified as essential. Two copies of the gospels (of the same edition) should be cut into columns, and made into a continuous text on one side only.

First.-Set out the text of the Nucleus in parallel columns of the three gospels. The references for this are given in the first columns of Tables I, II, III. Along with this may be kept in sequence the passages which are only in two gospels in sequence, as stated in the second columns of the tables. These are the first and second classes of documents, which were accreted before the separation of all the three gospels.

Second.-Set out similarly the text of all episodes which are parallel, and which come together in a block in any gospel, but which do not recur in the sequence with the Nucleus in different gospels. These are in the third columns of Tables I, II, III, and are the scattered documents. 
Third.-Set out all remaining passages of each gospel separately, marking in cross references to all parallels. These are in the fourth and fifth columns of Tables I and II. Those verses which have cross references are the fourth and fifth classes above. The other verses are the sixth class, which comprises the material which is only found in one gospel. This systematises the whole text.

Tables are needful of the chapters and verses of the Nucleus, which are here supplied in the columns of Tables I, II, and III. Also of the passages in sequence in two gospels, Table IV. Also of the passages which are in sequence together, but are not placed uniformly in the Nucleus, Table V. Also of the passages which are in scattered sequence in each of the gospels, the documents which were not incorporated but only extracted, Table VI. Lastly, the doublet verses, Table VII. A list is also needed of all other cross references between the gospels, in order to search for any extracts recurring in the same order in different gospels; this is the only way to detect scattered portions of documents. 


\section{CHAPTER III}

THE CLASSES OF DOCUMENTS

\section{The Nucleus (I).}

WE may first note the respective proportions in which the different classes of documents constitute the gospel of Matthew:-(1) Original Nucleus, one-quarter; (2) Episodes arranged as in Mark only, less than one-fifth (there are practically none in common with Luke); (3) Episodes which are inserted at different places in other gospels, one-fifth; (4) Scattered verses following the order in other gospels, one-fiftieth; (5) Episodes entirely out of relation to their place in other gospels, one-fourteenth ; (6) Episodes entirely unknown otherwise, two-sevenths. Thus classes (4) and (5) are practically insignificant, but the other four classes each contribute a large share. 
The Nucleus is, by its nature, of closely the same length in each gospel. It amounts to nearly a quarter of the whole in Matthew and Luke, and to two-fifths in Mark. The insertions in the Nucleus are so frequent that there are seldom more than two or three episodes of Nucleus still left together; and in the two chapters of the Trial and Passion, so minute has been the gathering in of supplementary detail, that the verses are almost alternately of Nucleus and of insertions.

In the gospel of Luke the Nucleus was retained from the third to sixth chapters; after that there are only two portions of it (in chapters viii and ix) until the eighteenth chapter. Nearly ten chapters have here been inserted of entirely independent material which was gathered by Luke.

The historical view of the Nucleus and the tracing of its connections will be dealt with in the next chapter. Here we observe only the structural evidence, which is unquestionable. The text of the Nucleus is given here as an appendix. 


\section{The Two-gospel Sequences (II).}

In dealing with those episodes which occur in two gospels in the same part of the Nucleus, we touch one of the most interesting problems of the enquiry. In dealing with it we may be met by a positive assertion that the Marcan form is the earlier, and that no other conclusion is open. On the contrary, in all the small details of words, it appears that Mark has a later form than Matthew. These facts are put in an appendix, to avoid a long digression here. At least, it must be granted that we must come to the structural evidence without any dictation from other criticism limiting our conclusions.

On looking at Table IV, we see the remarkable state of the connections between two gospels only. There are first two short passages of fourteen verses found in Matthew and Luke, which are probably accretions subsequent to Mark. Then come in strict sequence with the Nucleus five passages, ninety-eight verses, found in Mark and Luke, down to Mark vi. Of these there are three also in Matthew, but in different positions, 
and therefore accreted from documents independently. At this point the Mark-Luke connection practically ends, beyond this only seven scattered verses being in common sequence. Just before this break, begins the series of Matthew-Mark sequence connections which extend on to the end. What can be the explanation of this sharp change in the relation of the gospels to each other?

Can it be that Luke has omitted all these Matthew-Mark passages? From their nature that is very unlikely, as they were on subjects of importance in a Gentile gospel, including the defilement by words and not ceremonially, the faith of the Syro-Phoenician woman, the law of divorce, and the great commandment. None of these would be omitted intentionally by Luke. Also a theory of Lucan omissions would not account for the absence of any Matthew-Mark connections in earlier chapters.

Can it be that Luke had the Nucleus only before the Matthew-Mark additions were incorporated? But still that would not account for Luke having passages in sequence with Mark down to Mark vi and not beyond.

There seems to be only one solution to fit 
the case before us. This is that there was a break during the compilation of Mark's additions to the Nucleus. At first he was in contact with an early stage of Luke's gospel, and then abruptly in contact with an early stage of Matthew's gospel. This view would compel us to place Mark as contemporary with an early stage of the other evangelists, drawing upon their additions to the Nucleus, but ceasing his accretions long before Matthew and Luke ended the growth of their gospels.

\section{The Scattered Documents (III).}

We now turn to the third class of materials ; in this the same internal order is maintained in different versions, but they are inserted at different places in the three gospels. This class is therefore clearly marked out as having existed in the form of separate documents. These documents were then incorporated or extracted by the evangelists, at a date after the Nucleus had been added to in common by Mark and Luke, and by Matthew and Mark.

The principal document is the so-called Sermon on the Mount, here lettered A. This 
is always recognised as extending from Matt. $\mathbf{1}$ to vi 29. As, however, we see in Luke two later episodes following his extracts in the same order as they, so in Matthew it seems that the Sermon had received an accretion of two narratives, Matt. viii 5-13 and Matt. xi 2-24, before it was used by the evangelists. These are on the centurion's servant and the discourse about the Baptist. The character of the Sermon is remarkable for the absence of all detail of time and place in it, for the entirely ethical and fundamental character of it, and for the regular system and arrangement of it as a whole. It obviously belongs to the time when the relation of the new teaching to the old was the first question to the hearers, and when all the local and personal facts were familiar, and did not need any mention or allusion. It has every characteristic of an encheiridion compiled during the ministry or immediately afterwards.

Now, it is most instructive to see in what way Mark and Luke used this document (see Table V). Mark took out of it successively two passages, Mark ix 50 and xi 25-26. Luke used it largely when writing his great 
supplementary blocks of chapters, vi 20 to viii 18 and $\mathrm{x}$-xvii. His insertions shew that he went through it three times to select suitable quotations for his subjects. First he inserted his chapters vi 20-21, 22-23, 28-36, $37-42,31,43$; vii $10,18-35$; and $\mathrm{x} 12-16$, exactly in the order of the Sermon, excepting a single verse. This shews how we must look for a chain of scattered quotations in recognising the documentary source of other passages. Then he went through it a second time for his chapters xi to xiii, making ten extracts. Yet a third time he resorted to it for three sayings when writing chapter xvi; see Table V.

We here get a view into the way in which the documents were used, and how they were worked one after another, through and through, for the sake of grouping the material. But the portions of documents which we can thus identify are by no means the whole of them; for the recognition of the sources we are entirely dependent on one episode being quoted by two writers, in its original order between other quotations. No doubt there was much that was only quoted by one evangelist, or was not quoted at all. 
Another such document, of short length, C, is the accusation of satanic agency and its repudiation, Matt. xii 22-45. Less than half of this was inserted by Mark in iii 22-30, and this is in proper sequence with the Nucleus; but it was used by Luke in xi 14-32, out of sequence, and one verse in vi 45 . In short, it was being used in building up the same passages in which the previous document appears.

Another short document, E, condemning the Pharisees, appears in Matt. xxiii 8-39; it was used by Luke in his central block of new chapters, with inversions, Luke xi from 37 to 52.

A third short document, F, was used in all the gospels, but not in the order of the Nucleus. It contains three parables: of the tares, the mustard seed, and the leaven. These are in Matt. xiii 24-43 : of that 24-32 is abbreviated in Mark iv 26-32; and 31-33 is in Luke xiii 18-21. The last verses, $34-43$, are greatly abbreviated in Mark iv 33-34.

\section{The Use of Doublets.}

In the previous section, documents $\mathrm{A}$ and $\mathrm{C}$ were both similarly used, and it might well be 
asked why they are not regarded as having been originally one. Here we must turn to the subject of doublets for a reply. Scattered throughout all the gospels are occasional repetitions of a saying twice in one gospel; these are naturally termed doublets. A list of some of those which are most obvious is given in Table VII, with each side of the references tabulated in order. To see the utility of these, turn to the longest document, the Nucleus. In that there are most doublets in Luke, and we can see their meaning best there. Of the 11 doublets in all Luke, 7 are in the Nucleus as regards one side only; but there is not a single instance of both sides of a doublet occurring within the Nucleus. Their absence shows that when a passage was once used in a document, it was not repeated in the same document. Such a conclusion might be expected a priori, but we are here able to prove it. Thus we see that a doublet serves to shew that its two contexts are parts of different documents.

Now, in the sermon $A$, and in the document $\mathrm{C}$, there is a doublet, vii 17 and 20 (see the parallel in sequence, Luke vi 43) similar to 
xii 33 and 37. This indicates that the documents were independent. Similarly, in the sermon $\mathbf{A}$ and in $\mathbf{E}$ there is a doublet, Matt. v 34 and xxiii 22, which shews these were separate documents.

\section{The Disintegrated Documents (IV).}

The fourth class is that of documents which have been in all cases disintegrated and used for extracts. At first sight it seems farfetched to suppose that scattered verses in one gospel had any connection with scattered parallels in another. But we have learned much from the treatment of the Sermon on the Mount by Luke, who has a scattered chain of fragments shewing where it has been used. If one writer could thus break up and utilise a document, two or three writers may have done so; and thus there may only be left a chain of verses in the same order in each gospel, but widely scattered in quite different contexts. We have therefore to look for the occurrence of several episodes or sayings repeated in different gospels, in the same sequence though differing in context. Such a chain we can identify as portions of a 
document which has been differently treated by each writer.

We can therefore trace thus two scattered documents, the parallel quotations of which are given in the Appendix, Table VI, lettered B and $\mathrm{D}$.

The block Matt. ix 32 to xi 27, from which seven sayings are parallel in Mark and Luke, might be thought to be due to a misplaced part of the Nucleus. But there is a doublet with the Nucleus in $x$ 38-9 and xvi 24-5, which shews that this is an independent document, D. It seems to be an early form of a commission to the apostles.

The other document, B, is very scattered, from Matt. viii 23 to xxiv 41, which comprise fifteen passages parallel to Luke in the same order throughout, except a transposition of two in Luke xvii 25, 33. Where the Marcan parallel is already reckoned as parallel to either of the others in the Nucleus or twogospel sequences, it is marked $=$. These passages in the two gospels indicate that $B$ had been incorporated by both Matthew and Luke before Mark drew from either of them.

To thus find fifteen scattered passages 
remaining yet unchanged in their consecutive order in different gospels, is a very astonishing result, and it throws a flood of light on the working system of accretion in the gospels.

\section{The Isolated Episodes (V).}

The fifth class is that of isolated episodes or sayings, which are not in the same order or connection in different gospels. Of these there are about thirty in Matthew, mostly of one or two verses in length. The whole amount is not more than about seventy-five verses, or onefourteenth of the gospel. This shews that not much use was made of short sayings or detached logia, from oral tradition which had no context.

\section{The Unrepeated Episodes (VI).}

The sixth class is of episodes which are only preserved in a single gospel, the material which is peculiar to each evangelist. In Matthew this is the largest class, two-sevenths of the whole; and it is much the same in Luke. But in Mark there are only two short passages, nine verses in all, which are peculiar to that gospel. This indicates that the second 
gospel was soon isolated from the fountainhead of material in Judaea, while Matthew seems to have long continued to add to his gospel, and Luke collected a large body of documents which he carried away out of reach of Mark to build up his extensive new chapters, quite independently of the gospel of Matthew, which remained in Jerusalem.

We have now seen how far purely structural criticism will lead us, without looking at the subjects of the documents or the connections of ideas involved in the arrangement.

Everything that has been brought to light is entirely clear of personal opinions or suppositions. It is difficult to see how any different conclusions could be reached from the mechanical facts of the sequences and of the distribution of episodes which lie before us. 


\section{CHAPTER IV}

HISTORICAL CONNECTIONS

\section{The Decades of Church History.}

Having now seen how far a purely impersonal sorting of the different classes of material can explain the structure of the gospels, we turn to the historical conditions for light on the periods of the documents thus separated. Down to this point, personal judgment has not had any scope; after this, the historical bearings have to be estimated.

It is to be expected that the successive stages of history of the early Church would be reflected in the character of the episodes which were thought most needful for public teaching. This does not at all imply that the episodes were invented at the appropriate time; but that, out of the large floating mass of written memoranda and oral tradition, certain parts successively caught the 
general attention of the Church, owing to their applicability to the questions of the period. These episodes, thus brought into prominence by the conditions of the time, were therefore incorporated in the Nucleus, or in the gospels which grew upon that.

There seems to be hardly a sufficient appreciation of the vital differences which existed in the interests and tone of the early Church from one decade to another. A question of organisation or of custom would arise, which had not been thought of ten years before, and which would never be debated ten years later. The rapid changes of the early Church, developing within a single generation from an almost crushed Jewish sect in Jerusalem to a power extending over the whole civilised world, necessitated an equally rapid adjustment of its outlook to the changing conditions. We will here notice the characteristics of each decade. In the dates given we are not concerned with the small differences of two or three years between various authorities, the order of the changes being our object here.

To about 30 A.D., during the ministry, the 
THE DECADES OF CHURCH HISTORY 35

problem to Jewish minds was the proper understanding of the law, which was not yet abrogated in any particular. "Think not that I am come to destroy the Law or the Prophets: I am not come to destroy, but to fulfil." The principles of the law, and their genuine application were the main subjects that appealed to the hearers. The Jew was eaten up with legality at the time, and the main question of the day to thoughtful minds was, how that burden should be lightened without losing the essential principles. The whole Sermon on the Mount is occupied with the discrimination of formalities and essentials. The interest in the baptism of John and his history also belongs to this age.

30-40. The period of the Church in Jerusalem is marked by the great questions of the relation of the Church as a community to the general mass of Judaism. The Temple was the centre of teaching, and only by the compulsion of persecution was the Church being forced into an independent attitude. We may gain some living impression of the situation by looking at the relation of the early Wesleyans to the Established Church. 
An order of friars or derwishes is similarly united by its special rules and beliefs, while yet subject to the religion and laws of the general community around it. Narratives became needful in order to explain the past events to the five thousand who had joined the new party (Acts iv 4).

40-50. The beginning of the next period is marked by the founding of churches outside of Jerusalem. That of Antioch is described, and there the definite title of Christians was adopted in 42. Quite as early must have been the Church of Alexandria, when we consider the enormous Jewish population of Egypt, and its close relation to Palestine. Stephen disputed with the synagogue of the Libyans, Cyrenians, and Alexandrians, before 36. The interest of the time lay in the Diaspora, and the equal importance of the Jewish communities wherever they might be. The Samaritans were welcomed, and Gentile proselytes such as the centurion Cornelius. The law was beginning to be regarded as partly obsolete or abrogated. Local explanations regarding scenes of narratives now became needful. 
50-60. The Gentile period was now developing. As early as 48 the Gentiles as a body asked for teaching at Antioch, and the first blast of the new age of the Church came in the open declaration, "seeing ye put it from you ... lo, we turn to the Gentiles." No longer must a Gentile be regarded as a proselyte. Even in the heart of Judaism the law was declared void by 48 or 50, and only the most fundamental morality was required to be observed by the Gentile converts. The road to Christianity no longer passed through Judaism. To this age there was a special meaning in the Prodigal Son, and in the subjection to kings and rulers. The explanations of the law now became necessary for the Gentiles to understand the narratives and allusions.

60-70. The age of external persecution and trouble began with Paul being sent a prisoner to Rome in 60. It was in full course in Nero's persecution in the year 64 in Rome. Paul's martyrdom followed in 66. The immense national tragedy of the fall of Jerusalem in $\mathbf{7 0}$ must have shaken the Jewish world far more than the fall of Rome shook 
the Roman world, as it involved the religious as well as the national centre. Henceforward Christianity lost its sense of any tie to Judaism.

Now, looking at the characteristics of these periods, we see how not only was there an entirely new problem and new atmosphere of thought in each decade, but also how the interests and questions of one or two decades before or after had either passed away or were as yet unthought of. And when we notice how the fulfilling of the law is the main theme of the Nucleus, and how little of the completed gospels refer to the Gentile problems, we must see how devoid of historic sense is the anachronism of supposing the main body of the gospels to have originated as late as the Gentile period.

\section{The Historic Position of the Nucleus.}

We are now prepared to estimate the position shewn by the Nucleus in relation to the known history. When we search through it, as given in the Appendix, there is not a single idea or incident recorded which steps beyond the field of thought of the ministry and of the 
HISTORIC POSITION OF THE NUCLEUS 39

Church at Jerusalem in its earlier growth. Even in the stage after this the Syro-Phoenician was still looked on as a "dog" not worthy of the children's bread.

When the geographical position is regarded the result is still more trenchant. Galilee is only vaguely named without indicating a single locality. There is but one precise statement of any place north of Jerusalem and Jericho. That exception is Caesarea (Matt. xvi 13), and that exactly localised account was doubtless due to Philip the evangelist of Caesarea (Acts xxi 3), who was at Jerusalem by 30 A.D. (Acts vi 5). Otherwise it seems that during the formation of the Nucleus, and before the separate gospels began to be constructed upon it, the Galilean ministry was but vaguely realised by the Church at Jerusalem.

The narratives are quite different as soon as we touch the later period of only two gospels in sequence. By the time of that growth the Galilean narratives had come to be incorporated, and we find named Capernaum, Tyre, Sidon, Gadara, Magdala, Dalmanutha, the SyroPhoenician, and Jairus. This local detail is foreign to the Nucleus, and its absence shews 
how entirely that belonged to the Jerusalem Church, while the names in the northern episodes were brought in from documents which had originated in Galilee.

Another strong evidence of the early date of the Nucleus is its treatment of the Resurrection period. It is full of minute detail down to the Burial; but only three or four verses at the utmost can be in the common basis of the gospels regarding the Resurrection. Yet the Resurrection was preached at a very early date (Acts ii 32 ; iv 2, 33; vii 56 ; x 40), and were the Nucleus even ten years later there would have been a full record about it. The close of the Nucleus suggests a document drawn up within a few months of the final events.

Now that the Nucleus is before us in the Appendix, it may be noticed how various links of episodes have been broken by the insertion of additions, even at a very early period of growth. The references here are to Matthew. After the preaching of the Baptist, the call of Simon and Andrew (iv 22) is continuous with the going into Simon's house (viii 14). After saying that the sick were brought (viii 16), 
there follows (ix 2) a case of palsy. The position of new doctrine is illustrated by the parables of the old garment and old bottles (ix 7) continued in (xii 1) the episode of eating corn on the Sabbath and healing on the Sabbath. The statement of universal relationship to the disciples (xii 50) may well have been the close of a primitive group of narrative dealing with the early questions about the law. The succeeding matter refers more to the aspect of the Church. The miracle of the loaves (xiv 13-20) has been thrust in between the perplexity of Herod (xiv 1-2; Luke ix 7) and the answering paragraph (xvi 13-16; Mark viii 27-31). The setting of a child in the midst (xviii 1-5) was followed immediately by children being brought to be blessed (ix 13), though in Luke nine chapters have been interpolated between the two halves of the episode (Luke ix 48 to xviii 15). The final visit to Jerusalem and the Crucifixion occupied nearly half of the Nucleus, and were expanded by numerous small insertions afterwards. Such was the teaching of the Church in Jerusalem before the Galilean documents had been collected and incorporated. 
Though the extent of the Nucleus is selfdefined by the extent of matter in the same sequence in all three gospels, yet in the question of detail as to which of the three versions is nearest to the original, personal judgment must come in. The choice of wording which has been made here in the Appendix is settled by the adoption of whichever version appeared to be the simpler and earlier in its ideas and expressions. The result is that 161 verses of Matthew, 97 verses of Mark, and 3 verses of Luke were adopted as being apparently the earliest forms. But not a word is omitted which is found in all three versions. Further detail belongs to the domain of textual and verbal criticism, and in this immense field there is unlimited scope for research. Here we must limit our view to structural criticism.

\section{The Two-Gospel Additions.}

After the compilation of the Nucleus, the stage is reached where the additions to it were not universally used, but it began to grow on different lines into different gospels. Those double narratives which are in sequence 
with each other, and in the same sequence in the Nucleus, were the earliest independent accretions. We have seen that the structural facts lead to the conclusion that Mark was in contact with Luke for the earlier third, and in contact with Matthew for the later part of his gospel.

Can we trace the historical position of such a sudden change during the construction of Mark's gospel? Mark was with Paul in the journey of 45 A.D. and was taken by Barnabas in the journey of 49 A.D. As he lived at Jerusalem before these journeys (Acts xii 12), it is probable that he homed there later, after the journeys. The tradition of his Alexandrian episcopate is far too strong to be set aside; and it is impossible not to suppose that the immense Jewish population of Alexandria and the Delta, which was in constant intercourse with Judaea, would not be evangelised as readily as the more distant and pagan Antioch. The close of his episcopate was in the eighth year of Nero, 62 A.D. (Euseb. Ecc. Hist. ii 24), when we find that he had left Egypt and gone to Rome (Philemon 24). He seems thus to have resided at Alexandria somewhere 
between 49 and 62 ; and the need of a written record for his converts there would soon be felt.

Now, as Blass points out (Phil. Gos. 33), Luke went to Jerusalem in 54 and left in 56, during which time he acquired his "perfect understanding" from those who "from the beginning were eye-witnesses" (Luke i 2, 3). This would have been a very likely place and period for Mark to be compiling his gospel for his Egyptian converts, side by side with Luke.

Mark seems to have reached chapter vi, using the same material in the same order as Luke. Then apparently Luke left Jerusalem with all his collected material, as yet uncompiled beyond Luke ix. Mark then seems to have obtained a copy of the Nucleus with Matthew's additions so far as yet made, and from that finished his gospel for the Egyptian Christians. That he did not keep his gospel in Palestine for any length of time is shewn by his having no supplementary accretions that are not in Matthew and Luke, excepting one brief generality (iii 9-12), a brief miracle (viii 22-26), and the doubtful end (xvi 16-20), 
fourteen verses in all. He did not long remain surrounded by current tradition and documents, but was isolated with the early stage of Matthew's gospel from chapter vi onward. Such seems to be the most likely historical setting of the curious connections which we have seen on examining the passages which are common to any two gospels.

We may be met with the dogma that the gospels must be later than the destruction of Jerusalem, which is prophesied in them. That dogma has, however, been exploded by the historical facts quoted by Blass. Savonarola's prophecies, given in 1496 and printed in 1497, foretold the sack of Rome, even down to the detail of stabling horses in the churches, which took place in 1527. Such a detail seemed excessively unlikely before the rise of Lutheranism; yet it came to pass. Such close fulfilment cannot destroy the fact that Savonarola's prediction was printed thirty years before the event; no more, therefore, does the partial fulfilment of the less detailed prophecy against Jerusalem disprove the dating of the compilation of the gospels fifteen years before the event, or disprove the prophecy 
having been given forty years before the event. Whatever beliefs may be held about such facts, the historical parallel frees us from any $a$ priori limitations of dating.

\section{Connections of Scattered Documents.}

The third class of accretions is that of whole documents which were incorporated, or those from which selections have been used. One of the earliest of these documents, the Sermon on the Mount, is concerned with the fulfilment of the law and the true meaning of its principles, questions which belonged entirely to the period of the Ministry.

The allusions in Document C (in Appendix) to Jonah and the men in Nineveh, and the Queen of the South, all agree to that being of the same age.

The lines on the Pharisees, in E (Appendix), seem equally to be of the age of the Ministry. And the parables of the tares and the leaven, in $\mathrm{F}$ (Appendix), appear also to be early.

The whole group, therefore, is of early documents, applicable to conditions before those of the organised Church, although they 
were not incorporated till after the partition of the gospels.

The fourth class is of two documents which are entirely scattered into verses and short sayings, in D and B, Appendix. The group $D$ is concerned with the mission of the apostles, whose names it was needless to record until the Church had scattered from Jerusalem. This was apparently the earliest form of the evangelising orders.

The longer document, B, starts with Galilean narrative about the Gergesenes and Jairus ; it includes the evangelising orders, and the prediction of being taken before governors and kings, and being persecuted, and the predictions of the end. All this accords with its belonging to the Diaspora period down to 50, or even the Gentile period down to 60 , and points to its being a later document than the others.

\section{Changes in Expressions.}

Here we should note some usages and differences of expression and idea, which are of historical importance as indicating periods. Throughout the Nucleus the title "Son of 
Man" is constantly used; but we never find the title "Son of God." The period of this change is very definitely stated in the Acts. Stephen speaks of the Son of Man on the right hand of God. But after the conversion of Saul in 37 A.D., we read for the first time, "he preached Christ in the synagogues that he is Son of God." After that Peter continued, certainly till 40, to use his earlier expression of Jesus Christ of Nazareth (iii 6, iv 10, x 36 and 38). Hence the use of the title of "Son of God" marks the Diaspora period (A.D. 40 and onward), and had scarcely arisen in the Jerusalem period (A.D. 30 to 40 ).

In Matthew the "kingdom of heaven" is the usual term; whereas it is never found in Mark or Luke (nor in the later books), the term being there always the "kingdom of God." The only instance of the term "kingdom of God" in the Nucleus is in Matt. xix 24 ; there it is in a verse which is a repetition of the previous verse 23, where the kingdom of heaven is named. It is probable that this repetition is a parallel version, using the simile of the camel and the eye of a needle, which has been introduced from the margin. The "king- 
dom of heaven" is therefore the original expression throughout.

The term "gospel," euangelion, is a late one, not found before 53 A.D. It was freely used by Matthew and Mark, but never by Luke, and only twice in the Acts. On the other hand, the verb evangelise is commonly used by Luke and in the Acts, but never in Mark, and only once in Matthew. Such a usage strongly shews the common origin of Luke's gospel and Acts.

20. The Latest Additions.

The fifth class is of scattered sayings which are never in the same order in different gospels; and the sixth class is of sayings and episodes which only occur in one gospel. These classes are almost entirely in Matthew and Luke, and are the accretions which were added after the gospels had finally parted company. Naturally, much of these editions was of early material which had not yet been incorporated. But some passages seem by their subject to reflect the interests of the Diaspora and Gentile periods.

In Matthew the later passages seem to be 
the genealogy (of Jewish interest) and the first chapter. Also iv 23-5, viii 28-34 ("thou Son of God"), xi 25-27, xvii 24-27, xxi 28-32, the disobedient son, xxii 1-14 (the wedding guest) the fate of Judas and the field of blood "unto this day," in xxvii 3-10, and the Pilate episodes, xxvii 19, 24-5, 62-6, and xxviii 2-4, 11-18. Lastly, the Herod narrative in chapter ii seems late, and might well have been added owing to Nero's persecution.

Turning to Luke, a large mass of his gathering seems to be quite of the early period, but we can perhaps see the interests of the Diaspora and Gentiles in other passages. Such are the praise of the Samaritan (x 2537); Martha cumbered about much serving, reflecting on ceremonialism; and the address to the daughters of Jerusalem. Of the Gentile period may be the insertion of the episode iv 16-30, with the bitter remark that Elijah was sent to Sarepta, a city of Sidon, and none were cleansed but Naaman the Syrian. The whole of chapters $\mathrm{i}$ and ii and the genealogy seem to be late in interest, from the importance of Mary and the long canticles. The Pilate and Herod passage, xxiii 4-15, seems also to 
be later than the general narration in which it is inserted.

On looking at the localisation of the scattered sayings, it is seen that later documents were used than those of the Nucleus. As we have noted, the Nucleus names no localities in the north, but only Galilee in general, while the two-gospel additions bring in Galilean detail. In the scattered episodes in Matthew are Decapolis, Capernaum, Nazareth, Bethlehem, and the name Gergesenes or Gerasenes, otherwise Gadarenes in Mark and Luke. The carelessness of the Jerusalem compiler about Galilee is shewn by substituting "a certain ruler" for Jairus.

In Luke there are many Galilean names. One point shews that Luke collected his new material himself in visiting Galilee, and did not only use local documents which were brought from there. In an episode which he alone inserts (iv 28-9) "they in the synagogue ... thrust him out of the city, and led him unto the brow of the hill whereon their city was built." The description was written by one who describes a place which he has seen but not lived in; the city is strange- 
"their city" - and the position was remarkable and not familiar. A similar point is that Matthew and Mark, writing at Jerusalem, say "the Sea of Galilee," which no one in Galilee would call it. But Luke, collecting narrative in Galilee, uses the local name, "Sea of Gennesaret," which distinguished it from the other Galilean lake of Merom. We also find named by Luke, Nazareth, Capernaum, Nain, and the persons Mary of Magdala, Joanna wife of Chuza, Susanna, and Zacchaeus. These names bear out his having collected material apart from the self-centred Church of Jerusalem. And this accords with his statement that he collected material from those who "from the beginning were eye-witnesses" -that is, from the early preaching in Galilee.

\section{Summary.}

We may now summarise the general position which we have reached in this enquiry.

The common use of writing among the lower classes in Roman times, and also the presence of a professional scribe among the 
apostles, make it probable that early notes and documents of Christian teaching were in use. The need of a written record for the churches which were springing up in distant regions before 50 A.D., would make some formal collection of documents requisite by then. Some form of gospels was thus both probable and necessary at an early date.

The personal judgment of style and probabilities is so variable, that some form of impersonal criticism is required. Such is to be found in structural criticism, the results of which are matters of fact rather than of opinion. On applying this, we find that the main classes of material in the gospels are: the Nucleus of episodes in the same order in all three gospels; the additions in the same order common to two gospels; the additions irregularly inserted in two; the additions only in one gospel. The irregular additions are of whole documents, or of scattered sayings inserted in the same order, shewing how documents were read through to extract material.

The Nucleus was compiled, probably in Jerusalem, before any Galilean documents 
were publicly recognised there. All the classes of later additions have Galilean detail. In the two-gospel passages Mark and Luke are in common for more than a third; after that, Matthew and Mark are in common. This shews a change in the sources of Mark's additions to the Nucleus. Further, Mark ceased to add to his gospel after obtaining Matthew's help. The Sermon on the Mount is the longest, and apparently the earliest, document that was separately used by each writer. Other documents can be traced which were only used for extracts by each writer.

Taking historical facts into account, we see the changes of standpoint and of interests in each decade of the early Church. The subjects dealt with in the gospels are mostly those of importance before 40 A.D., while but little refers to the Diaspora and the Gentile stages of 50 and 60 A.D.

The Nucleus, when restored to shape by removing the accretions, shews continuity in (1) the call of Simon, followed by entering his house; (2) the parable of the old bottles, followed by the plucking corn on the Sabbath; (3) the setting a child in the midst, followed 
by children being brought to be blessed. All of these connections have been broken by many chapters of insertions. Such connections, and the absence of Galilean detail in the Nucleus, are entirely shewn by the structure without any effect of opinion or selection.

The relation of the gospels which is seen to be most likely is that Mark and Luke collaborated on additions to the Nucleus, when in Jerusalem, 54-ə̃6. After the first third was written, Luke left with his material which he had personally collected in Galilee, and finished his gospel elsewhere. Mark then obtained Matthew's gospel, so far as then accreted, and finished his gospel, which remained in Egypt isolated from further accretion.

No apology is needed for treating the personalities of the evangelists as historical. The age of the writings named from them is guaranteed by the early period of the dominant interests which are shewn. No other persons in that age could have usurped their places.

A great deal of research yet remains to be done in detail, as to the limits of the original documents, the periods at which they were 
inserted by each evangelist, and, the discrimination of cases where an episode has been omitted by one, or brought in from a different source by another. This involves all the questions of various readings, and of varying original editions, which are the subjects of textual criticism. Here we have only dealt with structural criticism, and some of its historical applications. 


\section{APPENDIX}

\section{THE NUCLEUS AND OTHER SEPARATE DOCUMENTS}

IN order to shew more clearly the results of this study, the Nucleus is here placed together. The extent of the text here is solely settled by the three synoptic gospels agreeing upon it in its present order. Where one gospel differs materially in order from others, then the probability is that the passage was inserted later, and was not in the general Nucleus which underlies all the gospels. There may have been other passages in the Nucleus originally, but this is the minimum, and it is very unlikely that any verse here included did not belong to the narrative before the growth of the separate gospels.

The episodes here are therefore placed together solely on structural grounds, apart from any question of opinion. But the selection, from among the three versions, of the one which seems the earliest form of each 
episode, is a secondary question. The preference has been given to that version which has most in common with the others, and which is therefore the least affected by later reflections and suggestions.

This text therefore represents as nearly as we can see it the narrative used in the Church at Jerusalem, probably before 40 A.D., certainly before 50 A.D., upon which the evangelists later built the gospels suited to their respective churches.

If we enquire what this was likely to have been called at that time, the term gospel-euangelion, or good tidings-was yet unknown. The euangelion never appears in the Nucleus, only once in a two-gospel passage, and not in Acts till 53 A.D.; but the term doctrine or teaching was used (Acts ii 42, v 28). The word Christian was not yet used, but the new teaching was called "the Way." Saul searched "if he found any of the Way" (Acts ix 2). The damsel with the spirit of Python said that Paul and Silas "shew unto us the Way of salvation" (Acts xvi 17). Aquila expounded "the Way of God" (Acts xviii 26). At Ephesos "divers spake evil of the Way" (Acts xix 9 ; and "there arose no small stir about the Way" (xix 23). "After the Way, which they call heresy, so worship I the God of my fathers" (Acts xxiv 14). The English version has obscured this term by mistranslating it "that way" instead of "the Way." Those who 
followed the Way were called "such as should be saved" (Acts ii 47). So, if a title were given to this Nucleus, it would probably have been :

\section{THE TEACHING OF THE WAY FOR SUCH AS SHOULD BE SAVED.}

John the Baptist came preaching in the wilderness of Judaea. And saying, Repent ye : for the kingdom of heaven is at hand. (For this is he that was spoken of by the prophet Esaias, saying, The voice of one crying in the wilderness, Prepare ye the way of the Lord, make his path straight.) And there went out unto him all the land of Judaea, and they of Jerusalem, and were all baptized of him in the river of Jordan, confessing their sins. And John preached, saying, There cometh one mightier than I after me, the latchet of whose shoes I am not worthy to stoop down and unloose. I indeed have baptized you with water: but he shall baptize you with the Holy Ghost.

And it came to pass in those days, that Jesus came from Galilee, and was baptized of John in Jordan. And straightway coming up out of the water, he saw the heavens opened, and the Spirit like a dove descending upon him: And there came a voice from heaven, saying, Thou art my beloved Son, in whom I am well pleased. And immediately the Spirit driveth him into the wilderness. And he was there in the wilderness forty days tempted of Satan; and was with the wild beasts.

Now after that Jesus came into Galilee, and began to preach, and to say, Repent: for the kingdom of heaven 
is at hand. And Jesus, walking by the sea of Galilee, saw two brethren, Simon called Peter, and Andrew his brother, casting a net into the sea : for they were fishers. And he saith unto them, Follow me, and I will make you fishers of men. And they straightway left their nets, and followed him. And going on from thence, he saw other two brethren, James the son of Zebedee, and John his brother, in a ship with Zebedee their father, mending their nets; and he called them. And they immediately left the ship and their father, and followed him. And when Jesus was come into Peter's house, he saw his wife's mother laid, and sick of a fever. And he touched her hand, and the fever left her: and she arose, and ministered unto them.

When the even was come, they brought unto him many that were possessed with devils: and he cast out the spirits with his word, and healed all that were sick: And, behold, they brought to him a man sick of the palsy, lying on a bed: and Jesus seeing their faith said unto the sick of the palsy; Son, be of good cheer; thy sins be forgiven thee. And, behold, certain of the scribes said within themselves, This man blasphemeth. And Jesus knowing their thoughts said, Wherefore think ye evil in your hearts? For whether is easier, to say, Thy sins be forgiven thee; or to say, Arise, and walk? But that ye may know that the Son of man hath power on earth to forgive sins (then saith he to the sick of the palsy), Arise, take up thy bed, and go unto thine house. And he arose, and departed to his house. But when the multitudes saw $i t$, they marvelled, and glorified God, which had given such power unto men.

And as he passed by, he saw Levi the son of Alphaeus sitting at the receipt of custom, and said unto him, Follow me. And he arose and followed him. And it came to pass, as Jesus sat at meat in the house, behold, many 
publicans and sinners came and sat down with him and his disciples. And when the Pharisees saw it, they said unto his disciples, Why eateth your Master with publicans and sinners? But when Jesus heard that, he said unto them, They that be whole need not a physician, but they that are sick. But go ye and learn what that meaneth, I will have mercy, and not sacrifice : for I am not come to call the righteous, but sinners to repentance.

Then came to him the disciples of John, saying, Why do we and the Pharisees fast oft, but thy disciples fast not? And Jesus said unto them, Can the children of the bridechamber mourn, as long as the bridegroom is with them? but the days will come, when the bridegroom shall be taken from them, and then shall they fast. No man putteth a piece of new cloth unto an old garment, for that which is put in to fill it up taketh from the garment, and the rent is made worse. Neither do men put new wine into old bottles: else the bottles break, and the wine runneth out, and the bottles perish : but they put new wine into new bottles, and both are preserved.

At that time Jesus went on the sabbath day through the corn; and his disciples were an hungred, and began to pluck the ears of corn, and to eat. But when the Pharisees saw it, they said unto him, Behold, thy disciples do that which is not lawful to do upon the sabbath day. But he said unto them, Have ye not read what David did, when he was an hungred, and they that were with him; How he entered into the house of God, and did eat the shewbread, which was not lawful for him to eat, neither for them which were with him, but only for the priests? Therefore the Son of man is Lord also of the sabbath. And he entered again into the synagogue; and there was a man there which had a withered hand. And they watched him, whether he would heal him on the sabbath day; that they might accuse him. And he saith unto 
the man which had the withered hand, Stand forth. And he saith unto them, Is it lawful to do good on the sabbath days, or to do evil? He saith unto the man, Stretch forth thine hand. And he stretched it out : and his hand was restored whole as the other. Then the Pharisees went out, and held a council against him, how they might destroy him. But when Jesus knew it, he withdrew himself from thence.

There came then his brethren and his mother, and, standing without, sent unto him, calling him. And the multitude sat about him, and they said unto him, Behold, thy mother and thy brethren without seek for thee. And he answered them, saying, Behold my mother and my brethren! For whosoever shall do the will of God, the same is my brother, and my sister, and mother.

The same day went Jesus out of the house, and sat by the sea side. And great multitudes were gathered together unto him, so that he went into a ship, and sat; and the whole multitude stood on the shore. And he spake many things unto them in parables, saying, Behold, a sower went forth to sow; And when he sowed, some seeds fell by the way side, and the fowls came and devoured them up: Some fell upon stony places, where they had not much earth : and forthwith they sprung up, because they had no deepness of earth: And when the sun was up, they were scorched; and because they had no root, they withered away. And some fell among thorns; and the thorns sprung up, and choked them: But other fell into good ground, and brought forth fruit, some an hundredfold, some sixtyfold, some thirtyfold. Who hath ears to hear, let him hear. And the disciples came, and said unto him, Why speakest thou unto them in parables? He answered and said unto them, Because it is given unto you to know the mysteries of the kingdom of heaven; but to them it is not given. When any one heareth the word 
of the kingdom, and understandeth it not, then cometh the wicked one, and catcheth away that which was sown in his heart. This is he which received seed by the way side. But he that received the seed into stony places, the same is he that heareth the word, and anon with joy receiveth it; yet hath he not root in himself, but dureth for a while: for when tribulation or persecution ariseth because of the word, by and by he is offended. He also that received seed among the thorns is he that heareth the word; and the care of this world, and the deceitfulness of riches, choke the word, and he becometh unfruitful. But he that received seed into the good ground is he that heareth the word, and understandeth it; which also beareth fruit, and bringeth forth, some an hundredfold, some sixty, some thirty.

Now Herod the tetrarch heard of all that was done by him : and he was perplexed, because that it was said of some, that John was risen from the dead.

(When Jesus heard of it, he departed thence by ship into a desert place apart: and when the people had heard thereof, they followed him on foot out of the cities. And Jesus went forth, and saw a great multitude, and was moved with compassion toward them. And when it was evening, his disciples came to him, saying, This is a desert place, and the time is now past; send the multitude away, that they may go into the villages, and buy themselves victuals. But Jesus said unto them, They need not depart; give ye them to eat. And they say unto him, We have here but five loaves, and two fishes. And he commanded the multitude to sit down on the grass, and took the five loaves, and the two fishes, and looking up to heaven, he blessed, and brake, and gave the loaves to his disciples, and the disciples to the multitude. And they did all eat, and 
were filled: and they took up bf the fragments that remained twelve baskets full.)

And Jesus went out, and his disciples, into the towns of Caesarea Philippi : and by the way he asked his disciples, saying unto them, Whom do men say that I am? And they answered, John the Baptist: but some say, Elias; and others, One of the prophets. And he saith unto them, But whom say ye that I am? And Peter answereth and saith unto him, Thou art the Christ. And he charged them that they should tell no man of him.

And he began to teach them, that the Son of man must suffer many things, and be rejected of the elders, and of the chief priests, and scribes, and be killed, and after three days rise again. Then said Jesus unto his disciples, If any man will come after me, let him deny himself, and take up his cross and follow me. For whosoever will save his life shall lose it: and whosoever will lose his life for my sake shall find it. For what is a man profited, if he shall gain the whole world, and lose his own soul? or what shall a man give in exchange for his soul? Whosoever therefore shall be ashamed of me and of my words, in this adulterous and sinful generation, of him also shall the Son of man be ashamed, when he cometh in the glory of his Father with the holy angels. Verily I say unto you, There be some standing here, which shall not taste of death, till they see the Son of man coming in his kingdom.

And after six days Jesus taketh Peter, James, and John his brother, and bringeth them up into an high mountain apart, and was transfigured before them: and his face did shine as the sun, and his raiment was white as the light. And, behold, there appeared unto them Moses and Elias talking with him. Then answered Peter, and said unto Jesus, Lord, it is good for us to be here : if thou wilt, let us make here three tabernacles; one for thee, and one 
for Moses, and one for Elias. While he yet spake, behold, a bright cloud overshadowed them : and behold a voice out of the cloud, which said, This is my beloved Son, in whom I am well pleased; hear ye him. And when they had lifted up their eyes, they saw no man, save Jesus only. And as they came down from the mountain, Jesus charged them, saying, Tell the vision to no man, until the Son of man be risen again from the dead.

And when they were come to the multitude, there came to him a certain man, kneeling down to him, and saying, Lord, have mercy on my son : for he is lunatick, and sore vexed: for ofttimes he falleth into the fire, and oft into the water. And I brought him to thy disciples, and they could not cure him. Then Jesus answered and said, $O$ faithless and perverse generation, how long shall I be with you? how long shall I suffer you? bring him hither to me. And Jesus rebuked the devil; and he departed out of him: and the child was cured from that very hour.

Jesus said unto them, The Son of man shall be betrayed into the hands of men: And they were exceeding sorry. At the same time came the disciples unto Jesus, saying, Who is the greatest in the kingdom of heaven? And Jesus called a little child unto him, and set him in the midst of them. And said, Whosoever shall humble himself as this little child, the same is greatest in the kingdom of heaven. And whoso shall receive one such little child in my name receiveth me. Then were there brought unto him little children, that he should put his hands on them, and pray: and the disciples rebuked them. But Jesus said, Suffer little children, and forbid them not, to come unto me : for of such is the kingdom of heaven.

And, behold, one came and said unto him, Good Master, what good thing shall I do, that I may have 
eternal life? And he said unto lim, Why callest thou me good? there is none good but one, that is, God: but if thou wilt enter into life, keep the commandments. He saith unto him, Which? Jesus said, Thou shalt do no murder, Thou shalt not commit adultery, Thou shalt not steal, Thou shalt not bear false witness, Honour thy father and thy mother. The young man saith unto him, All these things have I kept from my youth up. Jesus said unto him, If thou wilt be perfect, go and sell that thou hast, and give to the poor, and thou shalt have treasure in heaven: and come and follow me. But when the young man heard that saying, he went away sorrowful : for he had great possessions. Then said Jesus unto his disciples, Verily I say unto you, That a rich man shall hardly enter into the kingdom of heaven.

(And again I say unto you, It is easier for a camel to go through the eye of a needle, than for a rich man to enter into the kingdom of God.)

When his disciples heard $i t$, they were exceedingly amazed, saying, Who then can be saved? But Jesus beheld them, and said unto them, With men this is impossible; but with God all things are possible. Then answered Peter and said unto him, Behold, we have forsaken all, and followed thee. And Jesus said unto them, Verily I say unto you, That ye which have followed me, in the regeneration when the Son of man shall sit in the throne of his glory, ye also shall sit upon twelve thrones, judging the twelve tribes of Israel. And every one that hath forsaken houses, or brethren, or sisters, or father, or mother, or wife, or children, or lands, for my name's sake, shall receive an hundredfold, and shall inherit everlasting life.

And Jesus going up to Jerusalem took the twelve disciples apart in the way, and said unto them, Behold, we go up to Jerusalem; and the Son of man shall be 
betrayed unto the chief priests and unto the scribes, and they shall condemn him to death, and shall deliver him to the Gentiles to mock, and to scourge, and to crucify him: and the third day he shall rise again. And they came to Jericho: and as he went out of Jericho with his disciples and a great number of people, blind Bartimeus sat by the highway side begging. And when he heard that it was Jesus of Nazareth, he began to cry out, and say, Jesus, thou Son of David, have mercy on me. And many charged him that he should hold his peace : but he cried the more a great deal, Thou Son of David, have mercy on me. And Jesus stood still, and commanded him to be called. And Jesus said unto him, What wilt thou that I should do unto thee? The blind man said unto him, Lord, that I might receive my sight. And Jesus said unto him, Go thy way; thy faith hath made thee whole. And immediately he received his sight, and followed Jesus in the way.

And when they came nigh to Jerusalem, unto Bethphage and Bethany, at the mount of Olives, he sendeth forth two of his disciples, And saith unto them, Go your way into the village over against you: and as soon as ye be entered into it, ye shall find a colt tied, whereon never man sat; loose him, and bring him. And if any man say unto you, Why do ye this? say ye that the Lord hath need of him; and straightway he will send him hither. And they brought the colt to Jesus, and cast their garments on him; and he sat upon him. And many spread their garments in the way. And they that went before, and they that followed, cried, saying, Hosanna; Blessed is he that cometh in the name of the Lord: Hosanna in the highest.

And they come to Jerusalem : and Jesus went into the temple, and began to cast out them that sold and bought in the temple. And said unto them, It is written, My 
house shall be called the house of ${ }^{l}$ prayer; but ye have made it a den of thieves. And when the chief priests and scribes saw it they were sore displeased. And when he was come into the temple, the chief priests and the elders of the people came unto him as he was teaching, and said, By what authority doest thou these things? and who gave thee this authority? And Jesus answered and said unto them, I also will ask you one thing, which if ye tell me, I in like wise will tell you by what authority I do these things. The baptism of John, whence was it? from heaven, or of men? And they reasoned with themselves, saying, If we shall say, From heaven; he will say unto us, Why did ye not then believe him? But if we shall say, Of men; we fear the people; for all hold John as a prophet. And they answered Jesus, and said, We cannot tell. And he said unto them, Neither tell I you by what authority I do these things.

Hear another parable: There was a certain householder, which planted a vineyard, and hedged it round about, and digged a winepress in it, and built a tower, and let it out to husbandmen, and went into a far country: And when the time of the fruit drew near, he sent his servants to the husbandmen, that they might receive the fruits of it. And the husbandmen took his servants, and beat one, and killed another, and stoned another. Again, he sent other servants more than the first: and they did unto them likewise. But last of all he sent unto them his son, saying, They will reverence my son. But when the husbandmen saw the son, they said among themselves, This is the heir; come, let us kill him, and let us seize on his inheritance. And they caught him, and cast him out of the vineyard, and slew him. When the lord therefore of the vineyard cometh, what will he do unto those husbandmen? They say unto him, He will miserably destroy those wicked men, and will let out his vineyard 
unto other husbandmen, which shall render him the fruits in their seasons. Jesus saith unto them, Did ye never read in the scriptures, The stone which the builders rejected, the same is become the head of the corner.

And they sought to lay hold on him, but feared the people. And they sent unto him certain of the Pharisees and of the Herodians, to catch him in his words. And when they were come, they say unto him, Master, we know that thou art true, and carest for no man; for thou regardest not the person of men, but teachest the way of God in truth: Is it lawful to give tribute to Caesar, or not? But he knowing their hypocrisy, said unto them, Why tempt ye me? bring me a penny, that I may see $i t$. And they brought $i t$. And he saith unto them, Whose is this image and superscription? And they said unto him, Caesar's. And Jesus answering said unto them, Render to Caesar the things that are Caesar's, and to God the things that are God's. And they marvelled at him. Then come unto him the Sadducees, which say there is no resurrection; and they asked him, saying, Master, Moses wrote unto us, If a man's brother die, and leave his wife behind him, and leave no children, that his brother should take his wife, and raise up seed unto his brother. Now there were seven brethren : and the first took a wife, and dying left no seed. And the second took her, and died, neither left he any seed: and the third likewise. And the seven had her, and left no seed : last of all the woman died also. In the resurrection therefore, when they shall rise, whose wife shall she be of them? for the seven had her to wife. And Jesus answering said, When they shall rise from the dead, they neither marry, nor are given in marriage; but are as the angels which are in heaven. And as touching the dead, that they rise; have ye not read in the book of Moses, how in the bush God spake unto him, saying, I am the God of Abraham, and the God 
of Isaac, and the God of Jacob? He is not the God of the dead, but the God of the living.

And Jesus answered and said, while he taught in the temple, How say the scribes that Christ is the son of David? For David himself said by the Holy Ghost, The Lord said to my Lord, Sit thou on my right hand, till I make thine enemies thy footstool. David therefore himself calleth him Lord; and whence is he then his son? And he said unto them in his doctrine, Beware of the scribes, which love to go in long clothing, and love salutations in the marketplaces, and the chief seats in the synagogues, and the uppermost rooms at feasts.

And as he went out of the temple, one of his disciples saith unto him, Master, see what manner of stones and what buildings are here! And Jesus answering said unto him, Seest thou these great buildings? there shall not be left one stone upon another, that shall not be thrown down. And as he sat upon the mount of Olives, they asked him privately, Tell us when shall these things be? and what shall be the sign when all these things shall be fulfilled? And Jesus answering them began to say, Take heed lest any man deceive you: For many shall come in my name, saying, I am Christ; and shall deceive many. And when ye shall hear of wars and rumours of wars, be ye not troubled : for such things must needs be; but the end shall not be yet. For nation shall rise against nation, and kingdom against kingdom : and there shall be earthquakes in divers places, and there shall be famines and troubles: these are the beginnings of sorrows. But take heed to yourselves: for they shall deliver you up to councils. Now the brother shall betray the brother to death, and the father the son, and ye shall be hated of all men for my name's sake: then let them that be in Judea flee to the mountains. But woe to them that are with child, and to them that give suck in those days! 
For in those days shall be affliction, such as was not from the beginning of the creation. But in those days, after that tribulation, the sun shall be darkened, and the moon shall not give her light. And the stars of heaven shall fall. And then shall they see the Son of man coming in the clouds with great power and glory. Now learn a parable of the fig tree: When her branch is yet tender, and putteth forth leaves, ye know that summer is near: so ye in like manner, when ye shall see these things come to pass, know that it is nigh, even at the doors. Verily I say unto you, that this generation shall not pass, till all these things be done. Heaven and earth shall pass away: but my words shall not pass away.

After two days was the feast of the passover, and of unleavened bread: and the chief priests and scribes sought how they might take him by craft, and put him to death. But they said, Not on the feast day, lest there be an uproar of the people. And Judas Iscariot, one of the twelve, went unto the chief priests, to betray him unto them. And when they heard $i t$, they were glad, and promised to give him money. And he sought how he might conveniently betray him.

And the first day of unleavened bread, when they killed the passover, his disciples said unto him, Where wilt thou that we go and prepare that thou mayest eat the passover? And he said, Go into the city to such a man, and say unto him, The Master saith, Where is the guestchamber, where I shall eat the passover with my disciples? And the disciples did as Jesus had appointed them; and they made ready the passover. Now when the even was come, he sat down with the twelve. And as they did eat, he said, Verily I say unto you, that one of you shall betray me. And they were exceeding sorrowful, and began every one of them to say unto him, Lord, is it I ? The Son of man goeth as it is written of 
him, but woe unto that man by whom the Son of man is betrayed! And as they did eat, Jesus took bread, and blessed, and brake it, and gave to them, and said, Take eat; this is my body. And he took the cup, and when he had given thanks, he gave it to them : and they all drank of it. And he said unto them, This is my blood of the new testament, which is shed for many. Verily I say unto you, I will drink no more of the fruit of the vine, until that day that I drink it new in the kingdom of God. And Jesus saith unto them, All ye shall be offended because of me this night. Peter answered and said unto him, Though all men shall be offended because of thee, yet will I never be offended. Jesus said unto him, Verily I say unto thee, That this night, before the cock crow, thou shalt deny me thrice. Then cometh Jesus with them unto a place called Gethsemane, and saith unto the disciples, Sit ye here. And he went a little farther, and fell on his face, and prayed, saying, $\mathrm{O}$ my Father, if it be possible, let this cup pass from me : nevertheless not as I will, but as thou wilt. Then cometh he to his disciples, and saith unto them, Sleep on now.

And while he yet spake, lo, Judas, one of the twelve came, and with him a great multitude. And forthwith he came to Jesus, and said, Hail, master ; and kissed him. And, behold, one of them which were with Jesus stretched out his hand, and drew his sword, and struck a servant of the high priest's, and smote off his ear. Said Jesus to the multitudes, Are ye come out as against a thief with swords and staves for to take me? I sat daily with you teaching in the temple, and ye laid no hold on me. And they that had laid hold on Jesus led him away to Caiaphas the high priest, where the scribes and the elders were assembled. But Peter followed him afar off unto the high priest's palace, and went in, and sat with the servants, to see the end. 
The high priest asked him, and said unto him, Art thou the Christ, the Son of the Blessed? Jesus saith unto him, Thou hast said: nevertheless I say unto you, Hereafter shall ye see the Son of man sitting on the right hand of power, and coming in the clouds of heaven. Then the high priest rent his clothes, saying, He hath spoken blasphemy; what further need have we of witnesses? behold, now ye have heard his blasphemy. What think ye? They answered and said, He is guilty of death. Then did they spit in his face, and buffeted him ; and others smote him with the palms of their hands, saying, Prophesy unto us, thou Christ, Who is he that smote thee?

Now Peter sat without in the palace: and a damsel came unto him, saying, Thou also wast with Jesus of Galilee. But he denied before them all, saying, I know not what thou sayest. And when he was gone out into the porch, another maid saw him, and said unto them that were there, This fellow was also with Jesus of Nazareth. And again he denied with an oath, I do not know the man. And after a while came unto him they that stood by, and said to Peter, Surely thou also art one of them; for thy speech bewrayeth thee. Then began he to curse and to swear, saying, I know not the man. And immediately the cock crew. And Peter remembered the word of Jesus, which said unto him, Before the cock crow, thou shalt deny me thrice. And he went out, and wept bitterly.

When the morning was come, all the chief priests and elders of the people took counsel against Jesus to put him to death: And when they had bound him, they led him away, and delivered him to Pontius Pilate the governor. And Jesus stood before the governor: and the governor asked him, saying, Art thou the King of the Jews? And Jesus said unto him, Thou sayest. Therefore when they 
were gathered together, Pilate said unto them, Whom will ye that I release unto you? Barabbas, or Jesus which is called Christ? But the chief priests moved the people, that he should rather release Barabbas unto them. And Pilate answered and said again unto them, What will ye then that I shall do unto him whom ye call the King of the Jews? And they cried out again, Crucify him. Then Pilate said unto them, Why, what evil hath he done? And they cried out the more exceedingly, Crucify him. Then released he Barabbas unto them: and when he had scourged Jesus, he delivered him to be crucified.

And as they came out, they found a man of Cyrene, Simon by name: him they compelled to bear his cross. And when they were come unto a place called Golgotha, that is to say, a place of a skull, they crucified him, and parted his garments, casting lots. And set up over his head his accusation written, THIS IS JESUS THE KING OF THE JEWS. Then were there two thieves crucified with him, one on the right hand, and another on the left. And they that passed by reviled him. Likewise also the chief priests mocking him, with the scribes and elders, said, He saved others; himself he cannot save. If he be the King of Israel, let him now come down from the cross, and we will believe him. Now from the sixth hour there was darkness over all the land unto the ninth hour. And Jesus cried with a loud voice, and gave up the ghost. And the vail of the temple was rent in twain from the top to the bottom.

Now when the centurion saw what was done, he glorified God, saying, Certainly this was a righteous man. And all his acquaintance, and the women that followed him from Galilee, stood afar off, beholding these things. When the even was come, there came a rich man of Arimathaea, named Joseph, who also himself was Jesus' disciple. He went to Pilate, and begged the body of 
Jesus. And when Joseph had taken the body, he wrapped it in a clean linen cloth, and laid it in his own new tomb, which he had hewn out in the rock. And there was Mary Magdalene, and the other Mary, sitting over against the sepulchre.

In the end of the sabbath, as it began to dawn toward the first day of the week, came Mary Magdalene and the other Mary to see the sepulchre. And when they looked, they saw that the stone was rolled away: for it was very great. And entering into the sepulchre, they saw a young man sitting on the right side, clothed in a long white garment; and they were affrighted. And he saith unto them, Be not affrighted: ye seek Jesus of Nazareth, which was crucified: he is risen; he is not here. And they went out quickly, and fled from the sepulchre; for they trembled and were amazed.

$$
\text { [END OF NUCLEUS.] }
$$

\section{DOCUMEN'T A}

This will be found entire in Matt. $\mathbf{1}$ to vii 29. It received an accretion of narrative portions Matt. viii 1-13 and xi 2-24 before it was used in the gospels. 


\section{DOCUMENT B}

(A Galilean document of narratives and sayings, with an early form of commission to the disciples, before the list of apostles, scattered in fifteen portions, from Matt. viii 23 to Matt. xxiv 41 ; see Table VI.)

And when he was entered into a ship, his disciples followed him. And, behold, there arose a great tempest in the sea, insomuch that the ship was covered with the waves: but he was asleep. And his disciples came to him, and awoke him, saying, Lord, save us: we perish. And he saith unto them, Why are ye fearful, $O$ ye of little faith? Then he arose, and rebuked the winds and the sea; and there was a great calm. But the men marvelled, saying, What manner of man is this, that even the winds and the sea obey him!

And they came over unto the other side of the sea, into the country of the Gadarenes. And when he was come out of the ship, immediately there met him out of the tombs a man with an unclean spirit. But when he saw Jesus afar off, he ran and worshipped him. And cried with a loud voice, and said, What have I to do with thee, Jesus, thou Son of the most high God? I adjure thee by God, that thou torment me not. (For he said unto him, Come out of the man, thou unclean spirit.) And there was a good way off from them an herd of many swine feeding. So the devils besought him, saying, If thou cast us out, suffer us to go away into the herd of swine. And he said unto them, Go. And when they were come out, they went into the herd of swine: and, behold, the whole herd of swine ran violently down a steep place into the sea, and perished in the waters. 
And they that kept them fled, and went their ways into the city, and told every thing, and what was befallen to the possessed of the devils. And, behold, the whole city came out to meet Jesus : and when they saw him, they besought him that he would depart out of their coasts.

And when Jesus was passed over again by ship unto the other side, much people gathered unto him; and he was nigh unto the sea. And, behold, there cometh one of the rulers of the synagogue, Jairus by name; and when he saw him, he fell at his feet, and besought him greatly, saying, My little daughter lieth at the point of death: I pray thee, come and lay thy hands on her, that she may be healed; and she shall live. And Jesus arose, and followed him, and so did his disciples. And, behold, a woman which was diseased with an issue of blood twelve years, came behind him, and touched the hem of his garment: for she said within herself, If I may but touch his garment, I shall be whole. But Jesus turned him about, and when he saw her, he said, Daughter, be of good comfort; thy faith hath made thee whole. And the woman was made whole from that hour. And when Jesus came into the ruler's house, and saw the minstrels and the people making a noise, he said unto them, Give place : for the maid is not dead, but sleepeth. And they laughed him to scorn. But when the people were put forth, he went in, and took her by the hand, and the maid arose.

But when he saw the multitudes, he was moved with compassion on them, because they fainted, and were scattered abroad, as sheep having no shepherd. Then saith he unto his disciples, The harvest truly is plenteous, but the labourers are few; Pray ye therefore the Lord of the harvest, that he will send forth labourers into his harvest. And as ye go, preach, saying, The kingdom of heaven is at hand. Provide neither gold, nor silver, nor 
brass in your purses, nor scrip for your journey, neither two coats, neither shoes, nor yet staves : for the workman is worthy of his meat. And into whatsoever city or town ye shall enter, inquire who in it is worthy; and there abide till ye go thence. And when ye come into an house, salute it. And if the house be worthy let your peace come upon it: but if it be not worthy, let your peace return to you. And whosoever shall not receive you, nor hear your words, when ye depart out of that house or city, shake off the dust of your feet. Verily I say unto you, It shall be more tolerable for the land of Sodom and Gomorrha in the day of judgment, than for that city. Behold, I send you forth as sheep in the midst of wolves : for they will deliver you up to the councils, and they will scourge you in their synagogues; and ye shall be brought before governors and kings for my sake, for a testimony against them and the Gentiles. But when they deliver you up, take no thought how or what ye shall speak: for it shall be given you in that same hour what ye shall speak. For it is not ye that speak, but the Spirit of your Father which speaketh in you. Fear them not therefore: for there is nothing covered, that shall not be revealed; and hid, that shall not be known. What I tell you in darkness, that speak ye in light: and what ye hear in the ear, that preach ye upon the housetops. And fear not them, which kill the body, but are not able to kill the soul : but rather fear him which is able to destroy both soul and body in hell. Are not two sparrows sold for a farthing? and one of them shall not fall on the ground without your Father. But the very hairs of your head are all numbered. Fear ye not therefore, ye are of more value than many sparrows. Whosoever therefore shall confess me before men, him will I confess also before my Father which is in heaven. But whosoever shall deny me before men, him 
will I also deny before my Father which is in heaven. Think not that I am come to send peace on earth : I came not to send peace, but a sword. For $\mathrm{I}$ am come to set a man at variance against his father, and the daughter against her mother, and the daughter in law against her mother in law. And whosoever speaketh a word against the Son of man, it shall be forgiven him : but whosoever speaketh against the Holy Ghost, it shall not be forgiven him, ... O ye hypocrites, ye can discern the face of the sky; but can ye not discern the signs of the times?

From that time forth began Jesus to shew unto his disciples, how that he must go unto Jerusalem, and suffer many things of the elders and chief priests and scribes, and be killed, and be raised again the third day. For whosoever will save his life shall lose it; but whosoever shall lose his life for my sake the same shall save it. . . . But whoso shall offend one of these little ones which believe in me, it were better for him that a millstone were hanged about his neck, and that he were drowned in the depth of the sea. Woe unto the world because of offences! for it must needs be that offences come; but woe to that man by whom the offence cometh! Wherefore if thy hand or thy foot offend thee, cut them off, and cast them from thee: it is better for thee to enter into life halt or maimed, rather than having two hands or two feet to be cast into everlasting fire. And if thine eye offend thee, pluck it out, and cast it from thee : it is better for thee to enter into life with one eye, rather than having two eyes to be cast into hell fire. Moreover, if thy brother shall trespass against thee, go and tell him his fault between thee and him alone : if he shall hear thee, thou hast gained thy brother. Then came Peter to him, and said, Lord, how oft shall my brother sin against me, nd I forgive him? till seven times? Jesus saith unto him, I say not unto thee, Until seven times: but, 
Until seventy times seven. (And the apostles said unto the Lord, Increase our faith.) And the Lord said, If ye had faith as a grain of mustard seed, ye might say unto this sycamine tree, Be thou plucked up by the root, and be thou planted in the sea; and it should obey you.

But as the days of Noe were, so shall also the coming of the Son of man be. For as in the days that were before the flood they were eating and drinking, marrying and giving in marriage, until the day that Noe entered into the ark, and knew not until the flood came, and took them all away; so shall also the coming of the Son of man be. Let him which is on the housetop not come down to take anything out of his house : neither let him which is in the field return back to take his clothes. Then shall two be in the field; the one shall be taken, and the other left. Two women shall be grinding at the mill ; the one shall be taken, and the other left.

\section{DOCUMENT C}

On the recognition of Divine action. Luke xi 14, 15 ; Matt. xii 25-45.

And he was casting out a devil, and it was dumb. And it came to pass, when the devil was gone out, the dumb spake; and the people wondered. But some of them said, $\mathrm{He}$ casteth out devils through Beelzebub the chief of the devils. And Jesus knew their thoughts, and said unto them, Every kingdom divided against itself is brought to desolation; and every city or house divided against itself shall not stand: And if Satan cast out Satan, he is divided against himself; how shall then his kingdom stand? And if I by Beelzebub cast out devils, by whom 
do your children cast them out? therefore they shall be your judges. But if I cast out devils by the Spirit of God, then the kingdom of God is come unto you. Or else how can one enter into a strong man's house, and spoil his goods, except he first bind the strong man? and then he will spoil his house. He that is not with me is against me; and he that gathereth not with me scattereth abroad. Wherefore I say unto you, All manner of sin and blasphemy shall be forgiven unto men: but the blasphemy against the Holy Ghost shall not be forgiven unto men. Either make the tree good, and his fruit good; or else make the tree corrupt, and his fruit corrupt : for the tree is known by his fruit. A good man out of the good treasure of the heart bringeth forth good things : and an evil man out of the evil treasure bringeth forth evil things. For by thy words thou shalt be justified, and by thy words thou shalt be condemned.

Then certain of the scribes and of the Pharisees answered, saying, Master, we would see a sign from thee. But he answered and said unto them, An evil and adulterous generation seeketh after a sign; and there shall no sign be given to it, but the sign of the prophet Jonas: For as Jonas was three days and three nights in the whale's belly; so shall the Son of man be three days and three nights in the heart of the earth. The men of Nineveh shall rise in judgment with this generation, and shall condemn it : because they repented at the preaching of Jonas; and, behold, a greater than Jonas is here. The queen of the south shall rise up in the judgment with this generation, and shall condemn it: for she came from the uttermost parts of the earth to hear the wisdom of Solomon; and, behold, a greater than Solomon is here. When the unclean spirit is gone out of a man, he walketh through dry places, seeking rest, and findeth none. Then he saith, I will return into my house 
from whence I came out; and when he is come, he findeth it empty, swept, and garnished. Then goeth he, and taketh with himself seven other spirits more wicked than himself, and they enter in and dwell there: and the last state of that man is worse than the first. Even so shall it be also unto this wicked generation.

\section{DOCUMENT D}

An early form of the commission to the Apostles. Scattered in eight portions; see Table VI.

As they went out, behold, they brought to him a dumb man possessed with a devil. And when the devil was cast out, the dumb spake: and the multitudes marvelled, saying, It was never so seen in Israel. But the Pharisees said, $\mathrm{He}$ casteth out devils through the prince of the devils. And when he had called unto him his twelve disciples, he gave them power against unclean spirits, to cast them out, and to heal all manner of sickness and all manner of disease. Now the names of the twelve apostles are these; The first, Simon, who is called Peter, and Andrew his brother; James the son of Zebedee, and John his brother; Philip, and Bartholomew; Thomas, and Matthew the Publican; James the son of Alphaeus, and Lebbaeus, whose surname was Thaddaeus; Simon the Canaanite, and Judas Iscariot, who also betrayed him. And he said unto them, Is a candle brought to be put under a bushel, or under a bed? and not to be set on a candlestick? for there is nothing covered, that shall not be revealed; and hid, that shall not be known. What 
I tell you in darkness, speak ye in light: and what ye hear in the ear, preach ye upon the housetops. And fear not them which kill the body, but are not able to kill the soul : but rather fear him which is able to destroy both soul and body in hell. Are not two sparrows sold for a farthing? and one of them shall not fall on the ground without your Father. But the very hairs of your head are all numbered. Fear ye not therefore, ye are of more value than many sparrows. Whosoever therefore shall confess me before men, him will I confess also before my Father which is in heaven. But whosoever shall deny me before men, him will I also deny before my Father which is in heaven. And he said to them all, If any man will come after me, let him deny himself, and take up his cross daily, and follow me. For whosoever will save his life shall lose it: but whosoever will lose his life for my sake, the same shall save it. For what is a man advantaged, if he gain the whole world, and lose himself, or be cast away? And whosoever shall give to drink unto one of these little ones a cup of cold water only in the name of a disciple, verily I say unto you, he shall in no wise lose his reward. At that time Jesus answered and said, I thank thee, O Father, Lord of heaven and earth, because thou hast hid these things from the wise and prudent, and hast revealed them unto babes. Even so, Father : for so it seemed good in thy sight. All things are delivered unto me of my Father: and no man knoweth the Son, but the Father; neither knoweth any man the Father, save the Son, and he to whomsoever the Son will reveal him. 


\section{APPENDIX \\ DOCUMENT E \\ Denunciations. Matt. xxiii 13-39.}

But woe unto you, scribes and Pharisees, hypocrites! for ye shut up the kingdom of heaven against men: for ye neither go in yourselves, neither suffer ye them that are entering to go in. Woe unto you, scribes and Pharisees, hypocrites! for ye pay tithe of mint and anise and cummin, and have omitted the weightier matters of the law, judgment, mercy, and faith : these ought ye to have done, and not to leave the other undone. Woe unto you, scribes and Pharisees, hypocrites! for ye make clean the outside of the cup and of the platter, but within they are full of extortion and excess, because ye build the tombs of the prophets, and garnish the sepulchres of the righteous, and say, If we had been in the days of our fathers, we would not have been partakers with them in the blood of the prophets. Wherefore ye be witnesses unto yourselves, that ye are the children of them which killed the prophets. Wherefore, behold I send unto you prophets, and wise men, and scribes : and some of them ye shall kill and crucify; and some of them shall ye scourge in your synagogues, and persecute them from city to city; that upon you may come all the righteous blood shed upon the earth, from the blood of righteous Abel unto the blood of Zacharias son of Barachias, whom ye slew between the temple and the altar. Verily, I say unto you, All these things shall come upon this generation.

O Jerusalem, Jerusalem, thou that killest the prophets, and stonest them which are sent unto thee, how often would I have gathered thy children together, even as a hen gathereth her chickens under her wings, and ye would not! Behold, your house is left unto you desolate. For I say unto you, Ye shall not see me henceforth, till ye shall say, Blessed is he that cometh in the name of the Lord. 


\section{DOCUMEN'T F}

\section{Parables. Matt. xiii 24-34.}

Another parable put he forth unto them, saying, The kingdom of heaven is likened unto a man which sowed good seed in his field. But while men slept, his enemy came and sowed tares among the wheat, and went his way. But when the blade was sprung up, and brought forth fruit, then appeared the tares also. So the servants of the householder came and said unto him, Sir, didst not thou sow good seed in thy field? from whence then hath it tares? He said unto them, An enemy hath done this. The servant said unto him, Wilt thou then that we go and gather them up? But he said, Nay; lest while ye gather up the tares, ye root up also the wheat with them. Let both grow together until the harvest: and in the time of harvest I will say to the reapers, Gather ye together first the tares, and bind them in bundles to burn them : but gather the wheat into my barn.

Another parable put he forth unto them, saying, The kingdom of heaven is like to a grain of mustard seed, which a man took, and sowed in his field: which indeed is the least of all seeds : but when it is grown, it is the greatest among herbs, and becometh a tree, so that the birds of the air come and lodge in the branches thereof.

Another parable spake he unto them; The kingdom of heaven is like unto leaven, which a woman took, and hid in three measures of meal, till the whole was leavened. All these things spake Jesus unto the multitude in parables; and without a parable spake he not unto them. 


\section{THE CHOICE}

\section{BE'TWEEN MA'T'THEW AND MARK}

It has been so firm a canon of many critics that Mark's Gospel preceded Matthew's, as well as Luke's, that it is needful to clear the ground by seeing whether the reason for this canon is conclusive, and if we must accept it as limiting our possible results. Now, though we are dealing with structural criticism, yet, as the alleged grounds for the earlier date of Mark are textual and verbal, we will turn to this other kind of evidence, to see if it is conclusive. We shall not look to the whole gospel, as that is not here in question; but to those passages which are not in the nucleus common to all three gospels, and which are only found in Matthew and Mark. It is probable that these passages have a different descent to those of the nucleus. Also, we shall not here look at differences which depend on personal appreciation of a longer or shorter version as the more probable, but rather look at differences which imply earlier or later usage and thought.

We read in Matt., "Is not this the carpenter's son? is not his mother called Mary? . . ."(xiii 55). But in Mark, "Is not this the carpenter the son of Mary ... .?" (vi 3). Obviously Mark has the later form, in view of the Virgin-birth.

In Matt. xv 1-2 the scribes and Pharisees of Jerusalem make objection about the lack of ceremonial ablutions. In Mark vii 1-2 the Pharisees and scribes are said to have come from Jerusalem, and then to be shocked by the lack of the ablutions. Mark thus represents the unbelievers as coming with an objectless visit, and then starting a difficulty. Matthew has far the more likely account.

In Matt. xix 9 the abrupt change to the 1st person is due to the verbal insertion of the apposite saying from Matt. v 32, "And I say unto you, Whoever shall put away his wife ....;" this is transformed to the 3rd person by Mark. But if the Marcan 3rd 


\section{CHOICE BETWEEN MATTHEW AND MARK 87}

person were earlier in Mark x 11, 12, it would never have been transferred to the 1st person, in xix 9 by Matthew.

In Matt. xx 21 places are desired "in thy kingdom ;" in Mark $x 37$, " in thy glory." The kingdom was preached in the ministry, but the glory is a later development.

In Matt. xxiv 36 we read, of that day knoweth no man " not the angels of heaven, but the Father only." In Mark xiii 39 it is amplified as, " not the angels which are in heaven, neither the Son, but the Father"-clearly a later version. Matthew would never have omitted the Son, but Mark may well have inserted the words.

To those who knew the family, "Peter and the two sons of Zebedee" (Matt. xxvi 37), would be a natural locution; Mark explains it as "Peter and James and John" (xiv 33). The "two sons," rendered simply by the dual in semitic, is a shorter form of thought but not of actual expression, it belongs to the time when Zebedee's house was still the family unit, and would never at a later date be substituted for the names of James and John, when their persons were more thought of separately.

The multitude with swords and staves are said to come from the chief priests and elders of the people (Matt. xxvi 47), who were the legal authorities; but Mark inserts the scribes (xiv 43), who would have no right to send a guard for an arrest. Again the Marcan form is corrupt.

In Matt. xxvi 61 the accusation is made of saying, "I am able to destroy the temple of God, and to build it in three days," which is explained by John (ii 21) as meaning the body as the divine temple. Mark did not understand it, and amplified it as, "I will destroy this temple that is made with hands," referring to the temple of Jerusalem (xiv 58).

Matthew has the reply, "Thou hast said," as in the earlier passage xxvi 25, and in the later passage xxvii 11, and in Mark Xv 2; Mark, in xiv 62, uses the unparalleled form "I am" in reply, as trying to be clearer.

Matthew introduces casting lots on the garments (xxvii 35) as agreeing with the prophecy. Mark omits the prophecy (xv 24), and the incident of the lots is then pointless.

In Matt. xxvii 42, "If he be the king of Israel, let him now come down" accords with the superscription; but Mark (Xv 32) introduces "Let Christ the king of Israel descend," which breaks the continuity with the superscription.

Matthew, in xxvii 48-9, says, "one of them ran and took a sponge ... and gave him to drink. The rest said, Let be." Mark 
confuses these two opposite frames of mind, and has, "one ran and filled a sponge... and gave him to drink, saying, Let alone " (xv 36). The account of Matthew is the intelligible form, that of Mark is contradictory.

Thus in a dozen small details of words, which do not depend on any general tendency to amplify or condense, we see that Matthew has uniformly the more probable text, and Mark has some misunderstanding of that, or some anachronism of a later writer who was not personally aware of the facts. And in general, when comparing the versions, we find that Matthew has a more probable text than that of Mark. We do not wish here to use this evidence for constructive purposes; it is only given to shew that verbal criticism cannot prove that Mark has the earlier text and that Matthew has modified it. 


\section{T A B L E S}


TABLE I.-THE CLASSES OF DOCUMENTS WHICH COMPOSE MATTHEW'S GOSPEL.

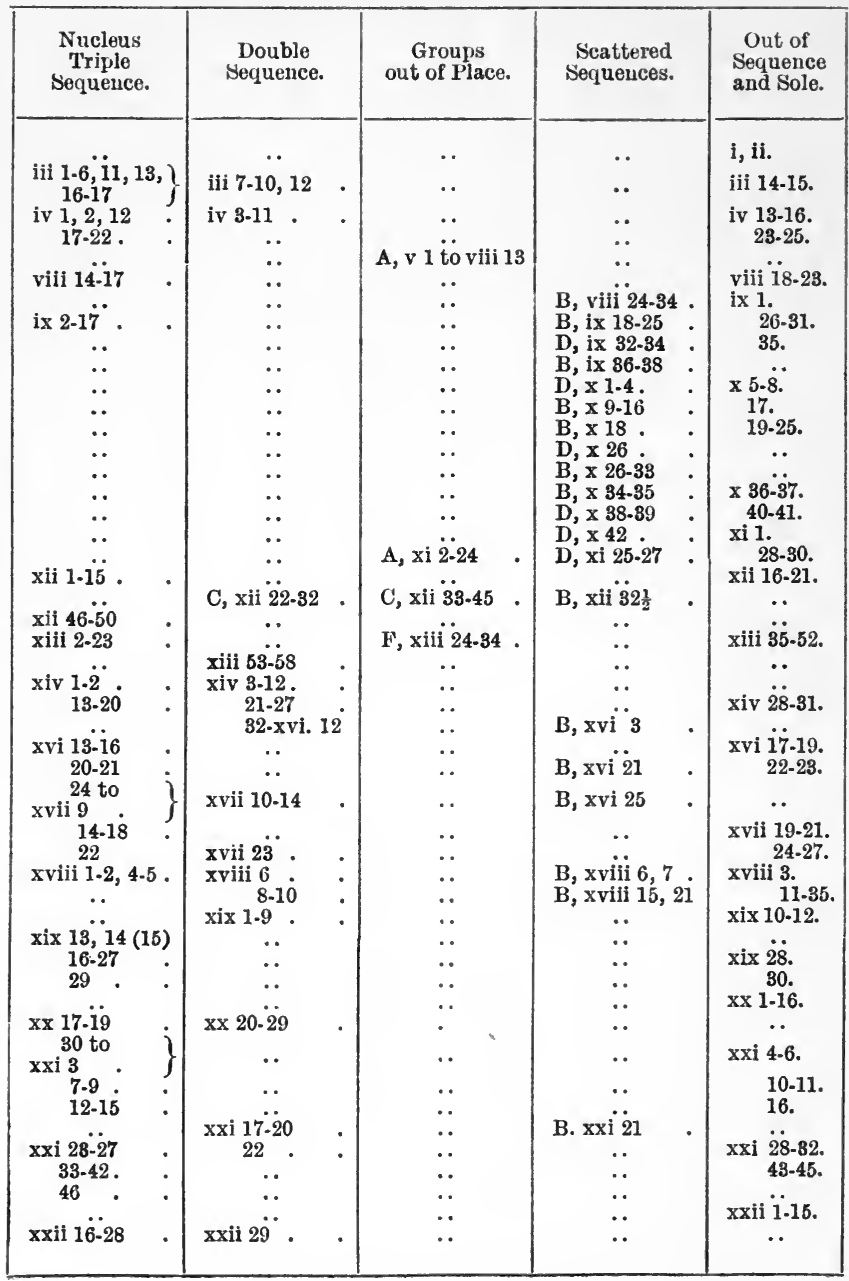


TABLE I.-Continued.

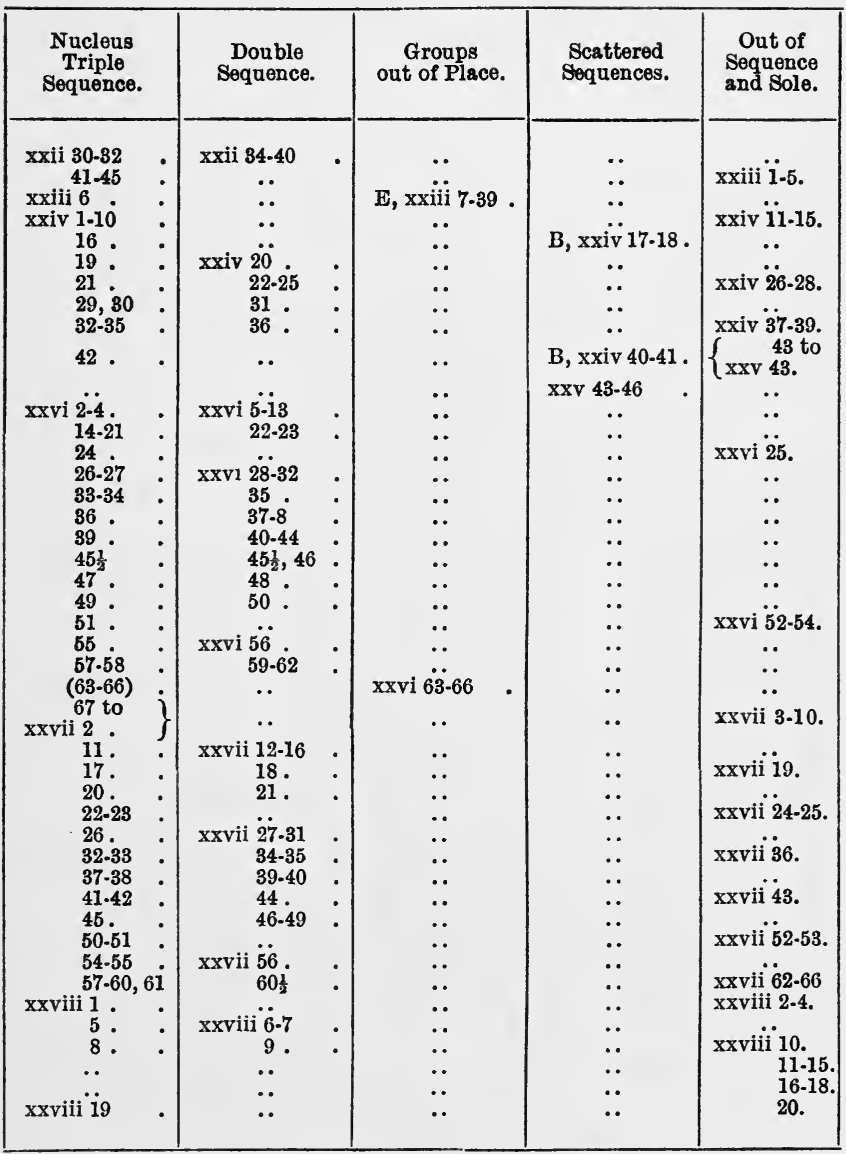


TABLE II.-THE CLASSES OF DOCUMENTS WHICH COMPOSE MARK'S GOSPEL.

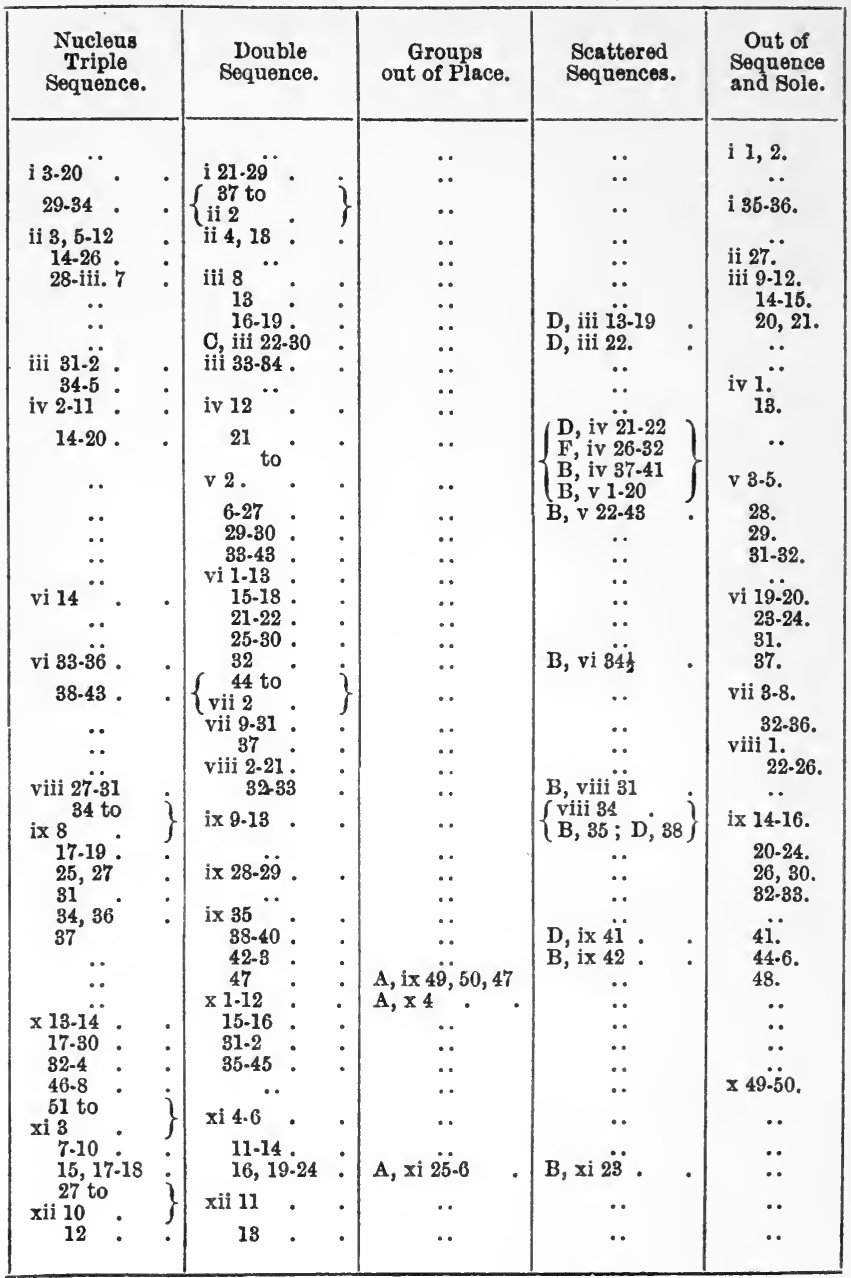


TABLE II.-Continued.

\begin{tabular}{|c|c|c|c|c|c|c|}
\hline $\begin{array}{c}\text { Nucleus } \\
\text { Triple } \\
\text { Sequence. }\end{array}$ & & $\begin{array}{c}\text { Double } \\
\text { Sequence. }\end{array}$ & & $\begin{array}{c}\text { Groups } \\
\text { out of Place. }\end{array}$ & $\begin{array}{l}\text { Scattered } \\
\text { Sequences. }\end{array}$ & $\begin{array}{l}\text { Out of } \\
\text { Sequence } \\
\text { and Sole. }\end{array}$ \\
\hline 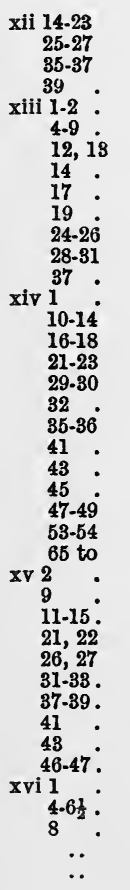 & : & 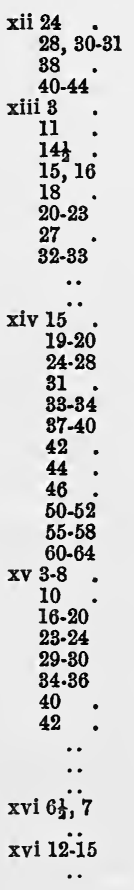 & : & 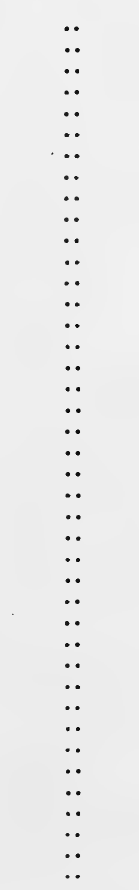 & 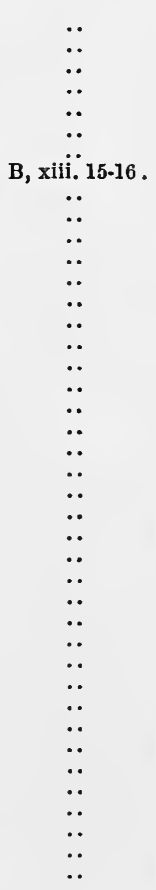 & 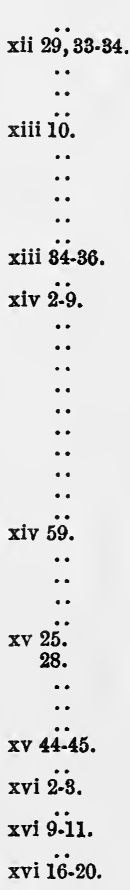 \\
\hline
\end{tabular}


TABLE III.-THE CLASSES OF DOCUMENTS WHICH COMPOSE LUKE'S GOSPEL.

\begin{tabular}{|c|c|c|c|c|c|}
\hline $\begin{array}{c}\text { Nucleus } \\
\text { Triple } \\
\text { Sequence. }\end{array}$ & $\begin{array}{c}\text { Double } \\
\text { Sequence. }\end{array}$ & $\begin{array}{c}\text { Groups out } \\
\text { of Place. }\end{array}$ & $\begin{array}{c}\text { Groups out } \\
\text { of Place. }\end{array}$ & $\begin{array}{l}\text { Scattered } \\
\text { Sequences. }\end{array}$ & $\begin{array}{l}\text { Out of } \\
\text { Sequence } \\
\text { and Sole. }\end{array}$ \\
\hline 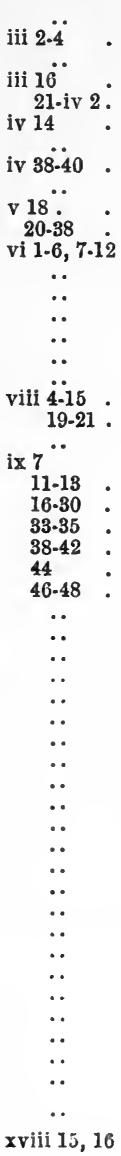 & 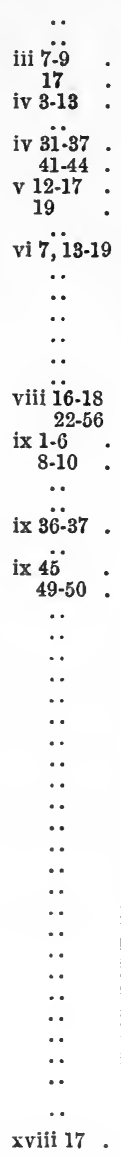 & 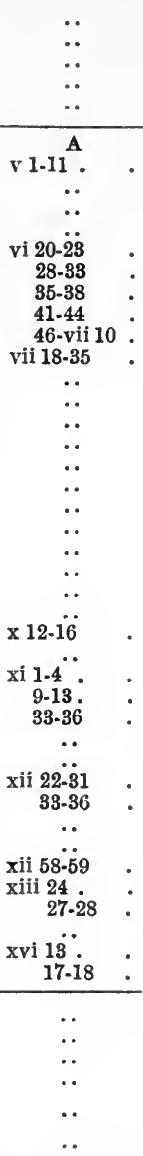 & 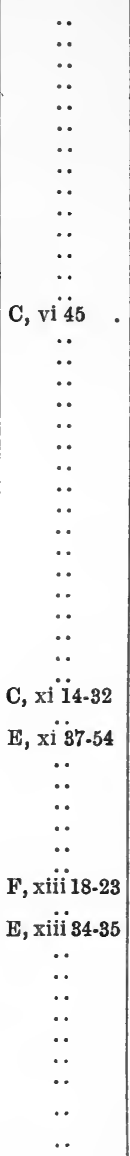 & 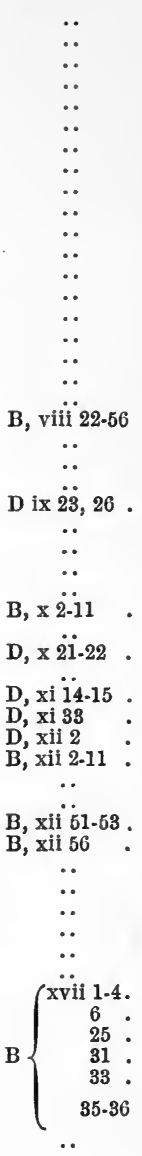 & 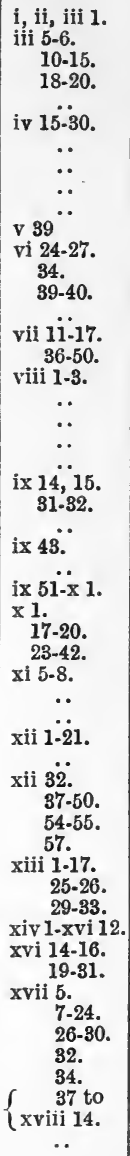 \\
\hline
\end{tabular}


TABLE III

TABLE III.-Continued.

\begin{tabular}{|c|c|c|c|c|c|}
\hline \multicolumn{2}{|c|}{$\begin{array}{l}\text { Nucleus Triple } \\
\text { Sequence. }\end{array}$} & \multicolumn{2}{|c|}{ Double Sequence. } & $\begin{array}{l}\text { Gronps out of } \\
\text { Place. }\end{array}$ & $\begin{array}{l}\text { Out of Sequence } \\
\text { and Sole. }\end{array}$ \\
\hline 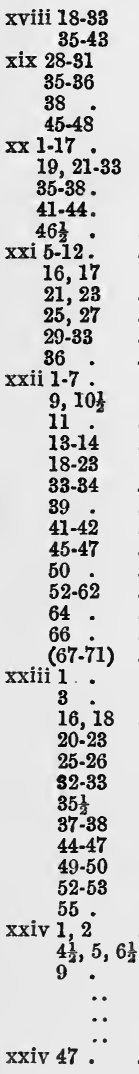 & 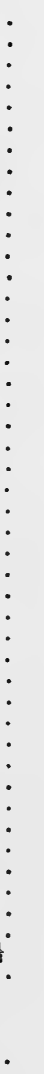 & 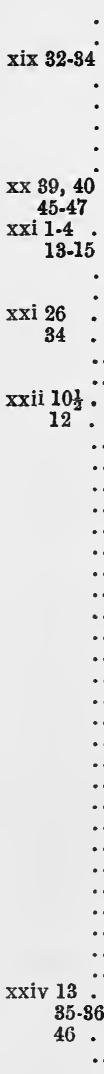 & : $\quad:$ & 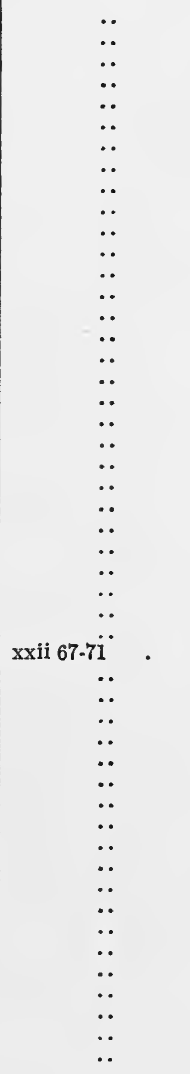 & 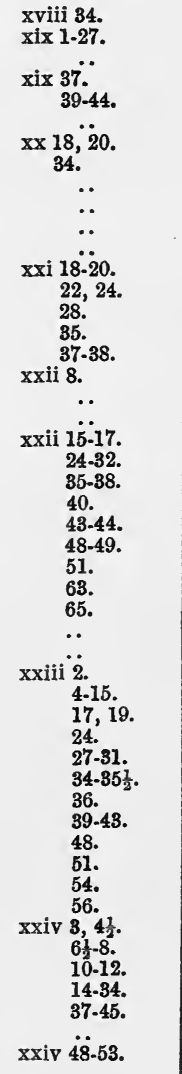 \\
\hline
\end{tabular}


TABLE IV.-DOCUMENTS IN SEQUENCE IN TWO GOSPELS ONLY.

\begin{tabular}{|c|c|c|c|c|c|}
\hline Matt. & Mark. & Mark. & Luke. & Matt. & Luke. \\
\hline $\begin{array}{l}\text { xii } 22-32 . \\
\text { xiii } 53-58 \\
\text { xiv } 3-12 . \\
22-27 \\
36-x v i \text { 12 } \\
\text { xviii } 8-x i x \text {. } \\
\text { xx 20-29. } \\
\text { xxii } 34-40 \\
\text { xxiv } 22-25 \\
36-37 \\
\text { xxvi } 5-13 \\
28-32 \\
35,37-8 . \\
40-44 \\
45-46 \\
48,59-66 . \\
\text { xxvii } 12-16 \\
27-31 \\
34-35 \\
39-41 \\
44,46-49 \\
55-56 \\
60-61 \\
\text { xxviii } 6-7 \\
9-10 \\
\end{array}$ & $\begin{array}{l}\text { iii } 22-30 . \\
\text { vi } 1-6 . \\
17-29 . \\
47-50 . \\
51-\text { viii } 21 . \\
\text { ix } 43 \text { to } \\
\text { x } 12 . \\
35-45 . \\
\text { xii } 28-34 . \\
\text { xiii } 20-23 . \\
32 . \\
\text { xiv } 2-9 . \\
24-28 . \\
31,33-4 . \\
37-40 . \\
41-2 . \\
44,55-64 . \\
\text { xv 3-7. } \\
16-20 . \\
23-24 . \\
29-30 . \\
32,34-36 . \\
40 . \\
46-7 . \\
\text { xvi } 6-7 . \\
9-10 .\end{array}$ & $\begin{array}{l}\text { i } 21-28 . \\
35-1 i 1 \\
\text { iii } 13-19 \\
\text { iv } 21-v 43 \\
\text { vi } 7-13 .\end{array}$ & $\begin{array}{l}\text { iv } 31-37 . \\
\text { v } 12-17 . \\
\text { vi } 13-16 . \\
\text { viii } 16-56 . \\
\text { ix 1-6. }\end{array}$ & $\begin{array}{l}\text { iii } 7 \cdot 10,12 \\
\text { iv } 3-11\end{array}$ & $\begin{array}{l}\text { iii } 7-9,17 \text {. } \\
\text { iv } 3-13 \text {. }\end{array}$ \\
\hline
\end{tabular}


TABLE V.-THE DOCUMENTS WHICH ARE IN SEQUENCE, NOT IN THE ORDER OF THE NUCLEUS, BUT INDEPENDENTLY USED.

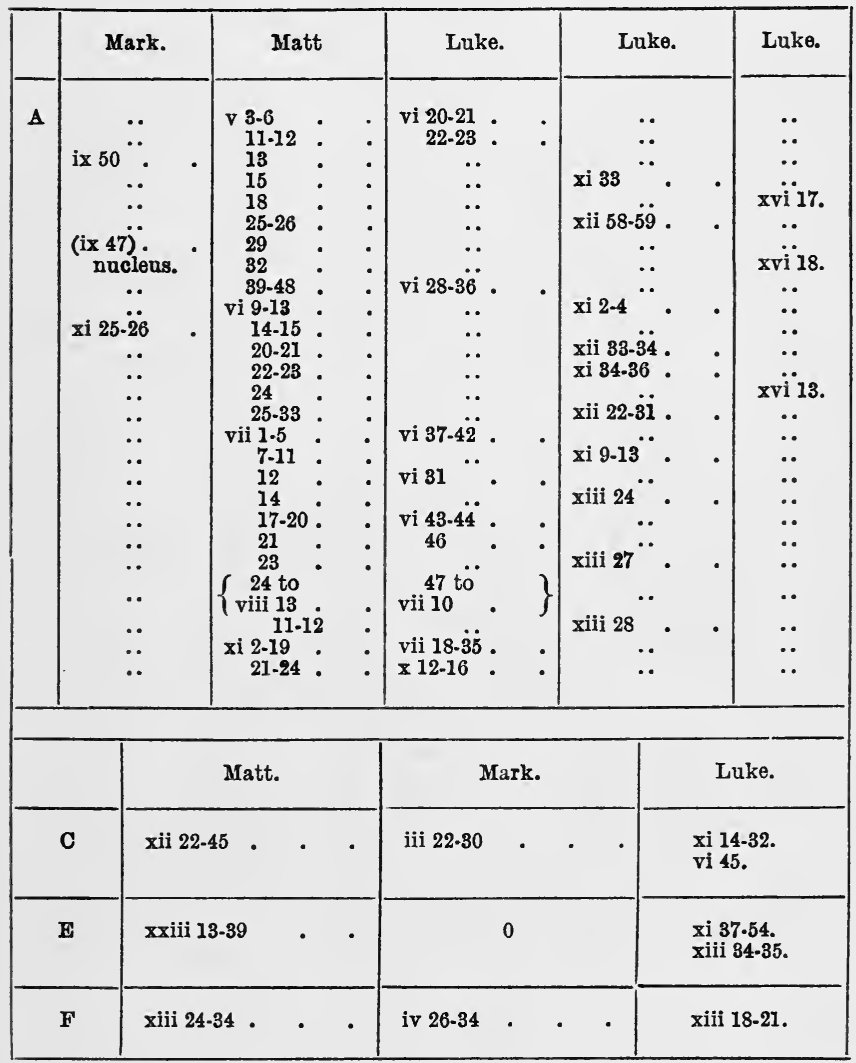


TABLE VI.-SCATTERED DOCUMENTS.

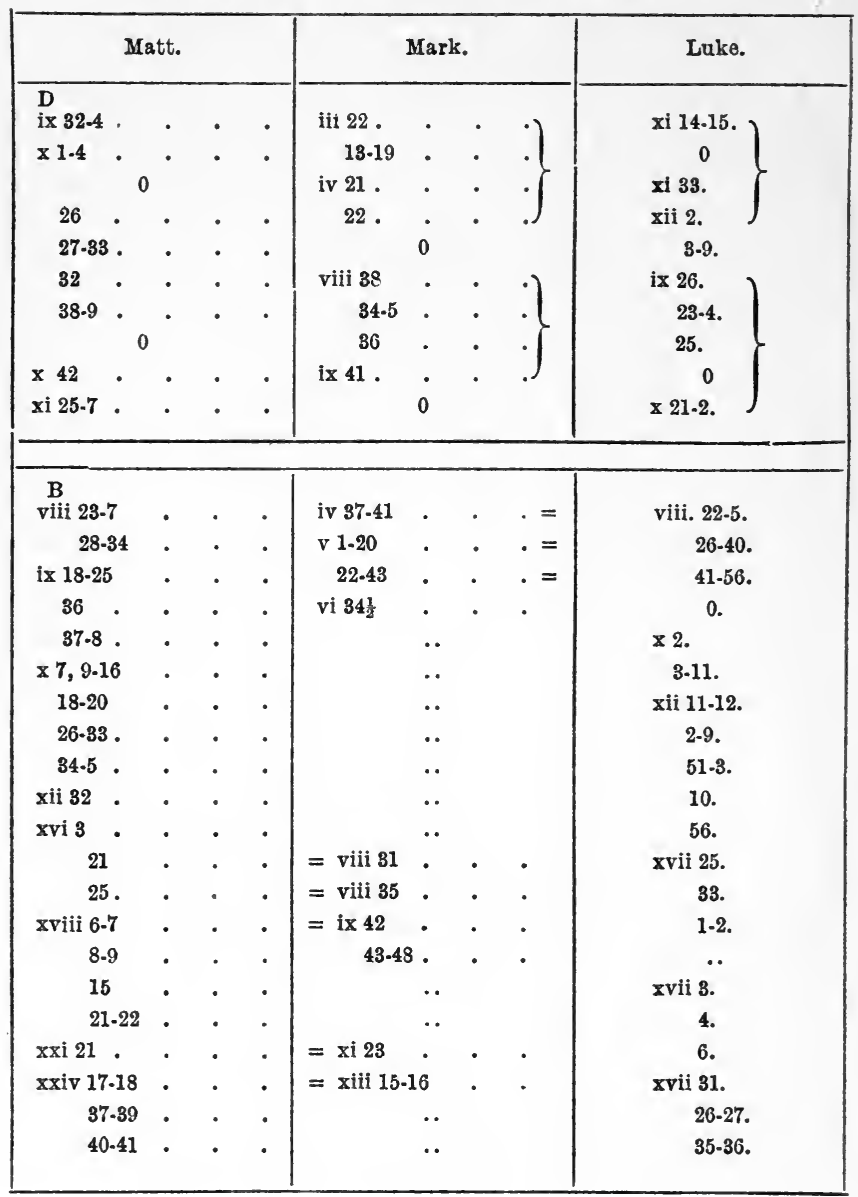




\section{TABLE VII.-DOUBLET VERSES.}

\begin{tabular}{|c|c|c|c|}
\hline & \multirow{3}{*}{$\begin{array}{l}=\quad \text { xviii } 9 \\
=\quad \text { xix } 7\end{array}$} & \multicolumn{2}{|c|}{ REVERSED. } \\
\hline v. 29 & & xi 24 & $=\quad \times 15$ \\
\hline 31 & & xii $22-24$ & $=$ ix 32.34 \\
\hline 34 & $=\quad$ xxiii 22 & 33,37 & $=$ vii $17,20$. \\
\hline vii 17,20 & $=\quad x i i 33,37$ & xvi $24-25$ & $=\quad x 38.39$ \\
\hline ix 24 & $=\quad x$ vii 33 & xvii 33 & $=\quad \mathrm{ix} 24$ \\
\hline $27-30$ & $=x \times 30-34$ & xviii 9 & $=\quad \mathrm{v} 29$ \\
\hline $32-34$ & $=$ xii $22-24$ & 11 & $=\quad \mathrm{ix} 56$ \\
\hline 56 & $=\quad$ xviii 11 & 18 & $=$ xvi 19. \\
\hline$\times 15$ & $=\quad x i 24$ & 21 & $=$ xvii 4 \\
\hline $38-39$ & $=\quad x v i$ 24-25. & xix 7 & $=\mathrm{v} 81$ \\
\hline xii 12 & $=x \times i 12-14$ & $x \times 16$ & $=\quad x i x 30$ \\
\hline xiii 12 & $=\quad \operatorname{xxv} 9$ & $30-34$ & $=\quad$ ix 27.30 \\
\hline xv 14 & $=\quad x x i i i 16$ & xxi 12-14 & $=\quad x i i 12$ \\
\hline xvi 19 & $=\quad x$ viii 18 & 21 & $=\quad$ xvii 20 \\
\hline xvii 4 & $=21$. & xxii 14 & $=x \times 16$ \\
\hline 20 & $=\quad x x i 21$ & xxiii 11 & $=26$. \\
\hline xix 30 & $=x \times 16$ & 16 & $=x \vee 14$ \\
\hline$x \times 16$ & $=\quad x x i i 14$ & 22 & $=\quad \mathrm{v} 34$ \\
\hline 26 & $=$ xxiii 11. & $x x \vee 29$ & $=$ xiii 12. \\
\hline & & & \\
\hline & & REV & ERSED. \\
\hline viii 16 & $=$ xi 33. & xi 33 & $=$ viii 16 \\
\hline 17 & $=\quad$ xii 2. & xii 2 & $=17$ \\
\hline 18 & $=\operatorname{xix} 26$ & $8-9$ & $=\quad \mathrm{ix} 26$. \\
\hline ix 22 & $=\quad$ xvii 25 & xiv 27 & $=23$. \\
\hline 23 & $=\quad \operatorname{xiv} 27$ & xvii 25 & 22. \\
\hline 24 & $=\quad x v i i 33$ & 33 & $=24$. \\
\hline 26 & $=\quad$ xii 8-9. & xviii 18 & $=\times 25$ \\
\hline 56 & $=\quad x i x 10$ & xix 10 & $=\quad \mathrm{ix} 56$ \\
\hline x 25 & $=\quad x v i i i 18$ & 26 & $=\quad$ viii 18 \\
\hline xi 43 & $=x \times 46$ & $\mathrm{xx} 46$ & $=x i$ \\
\hline xii 11 & $=x x i 12,14$ & $x \times i 12,14$ & $=$ xii 11. \\
\hline
\end{tabular}


PRINTED BY

OLIVRR AND BOYD

EDINBUROH 


\title{
RESEARCHES IN SINAI
}

\author{
WITH CHAPTERS BY \\ C. T. CURRELLY, M.A.
}

Officer of the Imperial Order of the Medjidie

With 186 Illustrations and 4 Maps. Demy 8vo. 2rs. net

"Necessity, as well as inclination, drew Mr Flinders Petrie's party last winter into the wilderness of Sinai. ... . That he has been richly rewarded, not merely by the more accurate examination of old finds, but by new and unexpected discoveries, is clearly attested by the present handsome volume."-Scotsman.

"It is no exaggeration to say that it is the most exhaustive work on the archæology of this historic peninsula that ever has appeared or ever will appear. The reason for this last statement is clearly set forth by the author, and is a record of one of the greatest acts of vandalism known. . . The most important portion of the work, however, is the description of the Hathor Temple at Serabit-el-Khadem. Space will not permit of our dealing so fully with these chapters as they deserve; but no student of religion should neglect the valuable material the author has gathered. . . In conclusion, we may say that this is a most valuable book, well written, lavishly illustrated, and well indexed." - Globe.

"This work, with its lavish amount of illustration and wealth of research, is, we have no hesitation in saying, the best book Professor Petrie has produced, and it will long remain the standard work on this historical peninsula, which links the African and Asiatic continents together."-Daily Chronicle.

"If proof were needed of the ancient overlordship of Egypt over the Bedawyn of the peninsula, it is supplied by Professor Petrie. - Of profound interest to Biblical scholars. . . Mr Petrie's ingenious theory restores to the Biblical story the historical verisimilitude, the lack of which was urged with great force by Bishop Colenso in the middle of last century. It should be added that the book is lavishly adorned with interesting and valuable photographs, taken by members of the expedition."-Daily Telegraph.

"Mr Flinders Petrie's great work. . . . Mr Flinders Petrie has added a new chapter to the exploration of the world."Church Times. 
A New Bible Dictionary, written by Leading Scholars of to-day, and including the results of modern research.

\section{MURRAY'S NEW ILLUSTRATED \\ B I B L E D I C T I O N A R Y Combining Modern Research with Ancient Faith}

Editor: The Rev. WILLIAM C. PIERCY, M.A.,

In One Volume. Price 21s.; half-morocco, $25 \mathrm{~s}$.

I. A volume of 1000 pages.

\section{SPECIAL FEATURES}

2. Profusely Illustrated, with Original Sketches, Reproductions from Photographs, Diagrams, and Coloured Maps.

3. Special attention has been paid to Bibliography, which has not before been attempted in a similar work of this size.

4. Signed Articles by Leading Scholars and Experts.

The size and price of this Dictionary make it available for many who cannot afford those published in several volumes, or who wish for a more handy book of reference; while the addition of Bibliographies to all important articles enable those who desire to do so to pursue any subject further; and the present volume should be found especially nseful to students at the Universities, Theological Colleges and Schools, the busy parochial clergy, and the laity.

Special attention has been paid to the illustrations, which it is hoped are such as will prove a really valuable aid to the understanding of the Bible.

A SMALLER BIBLE-DICTIONARY. For Schools and Young Persons. Maps and Woodcuts. Large Crown 8vo. Cheap Edition, 2s. 6d, net.

\section{A POPULAR HISTORY OF THE CHURCH OF} ENGLAND, from the Earliest Times to the Present Day. By the Right Rev. William Boyd-CARPENTER, Bishop of Ripon. With Illustrations. Cheap Edition. Large Crown 8vo. 2s. 6d. net.

"The title is, perhaps, hardly wide enough for the contents; one would almost call the book a history of Christianity in England. . . He has the true judicial spirit, and is passionately eager to be entirely fair to every one. His history is impartial to the last degree. . . His book should have a very wide circulation, and can do nothing but good wherever it is read." Morning Post.

OLD TESTAMENT HISTORY. By the Rev. J. M. HARDWICH, M.A., late Scholar of St John's College, Cambridge, and Bell University Scholar; and the Rev. H. Costrey-White, M.A., late Scholar of Balliol College, Oxford. In Five Periods. Crown 8vo. 2s. each Volume.

Vol. I. - From the Creation to the Crossing of the Red Sea.

Vol. II.-From the Crossing of the Red Sea to Ruth.

Vol. III.-From the Birth of Bamuel to the Death of David.

Vol. IV.-From the Accession of Solomon to the Fall of the Northern Kingdom.

Vol. V.-From Hezekiah to the end of the Canon. 
THE PSALMS IN HUMAN LIFE. By ROWLAND E. Prothero, M.V.O. Cheap Edition. Demy 8vo. 5s. net. Also an Edition, printed on India Paper, and bound up with the authorized Version of the Psalms. 5s. net.

"The improssion of the continuous influence exercised by "The Psalms in Human Life' is without doubt very striking. But it is very difficult to give within the compass of a review any notion of this effect." - Spectator.

"The great subject discussed by Mr Prothero in his fascinating book." Guardian.

THE HOLY EUCHARIST, with other Occasional Papers. By the Rev. P. N. WAGGETT, of the Society of St John the Evangelist, Cowley. 3s. 6d. net.

"The work of a thinker who has in him something of the poet and the mystic, who yet is no recluse or vague dreamer, but is in close and living contact with the facts of life and with the thoughts which men are thinking in the veritable world of to-day. It is the work of a scribe instructed nnto the kingdom of Heaven, who brings forth out of the unfailing treasure things new and old. . . There is much else in this volume which is worthy of attentive consideration. There are passages which show a penetrating knowledge of human nature, which exhibit a mind neither cynical nor unduly optimistic, but which understands and sympathises. It abounds in sentences of rare beauty and insight."-The Guardian.

\section{WORKS BY THE REV. H. C. BEECHING, M.A., D.Litt. Canon of Westminster}

\section{THE BIBLE DOCTRINE OF THE SACRAMENTS.} Six Lectures given in Westminster Abbey during Lent, rgo8. Crown 8vo. 2s. 6d. net.

This forms a companion volume to the author's previous volumes on "The Apostles' Creed " and "The Bible Doctrine of Atonement." The subjects of the Lectures are: The Doctrine of the-Sacraments; Baptism; Infant Baptism, and Confirmation; The Eucharist; The Lord's Own Teaching; The Apostolic Teaching; The Primitive Celebration.

THE APOSTLES' CREED. Six Lectures delivered in Westminster Abbey. Large Crown 8vo. 2s. 6d. net.

" Dr Beeching has succeoded in imparting an astonishing amount of instruction in his six lectures, and what is even more important, has given every one of his readers the chance of appreciating the modern standpoint and under. standing the position of the reverent student of Christian theology in this twentieth century of ours. This it is which gives the book its value. It is simple, so that all can understand; it is reverent, so that every Christian may enjoy it ; yet it is essentially modern, so that though much may appear freshly put, with at times a strange new light, the learning and ability are so obviously consecrated to God and His Church, that we are almost insensibly led on, and finish with an honest admiration of the method and its results. . We could wish that some of our Bishops wonld choose this book for their Lay Readers to study and discuss in conference. It is an admirable example of the application of quite modern methods to the study of an ancient formula, and a most successful introduction to both."-Layworker.

THE BIBLE DOCTRINE OF ATONEMENT. Six Lectures given in Westminster Abbey. By H. C. BEECHING, M.A., D.Litt., and ALEXANDER NAIRNe, M.A., Professor of Hebrew in King's College, London. Large Crown 8vo. 2s. 6 d. net.

Contents :-The Doctrine of the Atonement-The Epoch of the Prophets -The Levitical Law of Sacrifice-The Gospel of Jesus Christ-The Doctrine of St Paul's Epistles-Atonement in the Epistle to the Hebrews. 


\section{WOR KS BY \\ The Right Rev. CHARLES GORE, M.A., D.D. Bishop of Birmingham}

ORDERS AND UNITY. Crown 8vo. 3s. 6d. net. THE NEW THEOLOGY AND THE OLD RELIGION : Being Eight Lectures, together with Five Sermons. Crown $8 v 0$. 5s. net.

THE PERMANENT CREED AND THE CHRISTIAN IDEA OF SIN. Two Sermons preached before the University of Oxford. Large Crown 8vo. Paper Covers. 6d. net.

SPIRITUAL EFFICIENCY. The Primary Charge delivered at his Visitation to the Clergy and Churchwardens of his Diocese, October 1904. Demy 8vo. Paper Covers. Is. net.

WHY WE CHRISTIANS BELIEVE IN CHRIST. The Bampton Lectures. Shortened for popular use by Rev. T. C. FRY. Fcap. 8vo. Is, net.

THE BODY OF CHRIST. An Enquiry into the Institution and Doctrine of the Holy Communion. Crown 8vo. 2s. 6d. net.

THE MISSION OF THE CHURCH. Crown 8vo, 2s, 6 d. Sixth Thousand.

THE INCARNATION OF THE SON OF GOD. Bampton Lectures for I89I. Cheap Edition. Large Crown 8vo. 2s.6d.net. DISSERTATIONS ON SUBJECTS CONNECTED WITH THE INCARNATION. Cheap Edition. Large Crown 8vo. 2s. 6d. net.

A Series of Simple Expositions of Portions of the New Testament

Crown 8vo. Green cloth, 2s. 6d. net each.

THE SERMON ON THE MOUNT. Fourteenth thousand. Also an Edition in Paper Covers, 6d. net.

THE EPISTLE TO THE EPHESIANS. Twelfth thousand. THE EPISTLE TO THE ROMANS. Vol. I.-Chapters I. to VIII. Sixth thousand.

THE EPISTLE TO THE ROMANS. Vol. II.-Chapters IX. to the end. With Appendices.

\section{Edited by}

ESSAYS ON CHURCH REFORM. Cheap Edition. Crown 8vo. 5s. net.

LUX MUNDI. A Series of Studies in the Religion of the Incarnation. Cheap Edition. Crown 8vo. 2s. 6d, net. 



\section{DAY USE ${ }^{1}$}

\section{RETURN TO DESK FROM WHICH BORROWED}

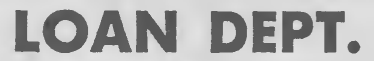

This book is due on the last date stamped below, or on the date to which renewed.

Renewed books are subject to immediate recall.

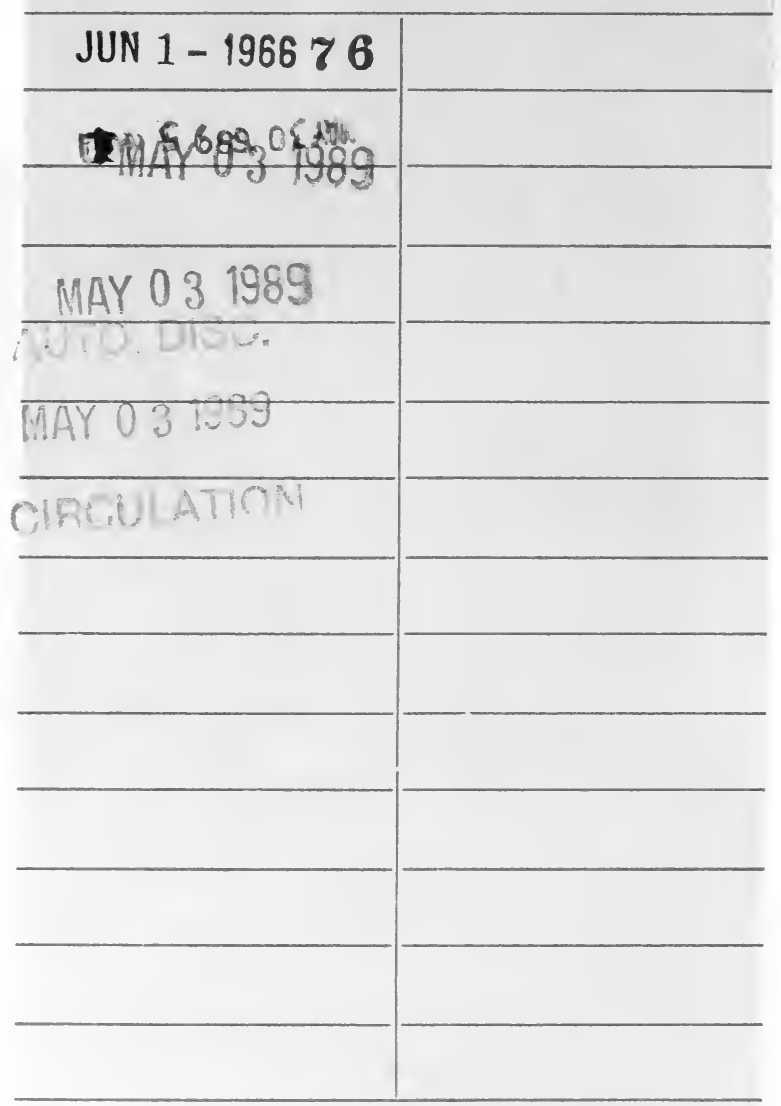




\section{U.C. BERKELEY LIBRARIES

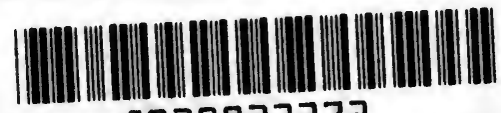 C020923272}
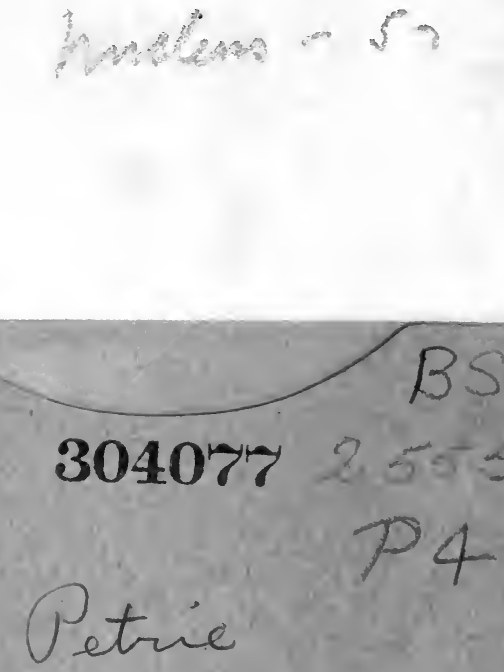

UNIVERSITY OF CALIFORNIA LIBRARY 
